\title{
Different sources and degradation state of dissolved, particulate, and sedimentary organic matter along the Eurasian Arctic coastal margin
}

DOI:

10.1002/2015GB005307

\section{Document Version}

Final published version

Link to publication record in Manchester Research Explorer

Citation for published version (APA):

Karlsson, E., Gelting, J., Tesi, T., Van Dongen, B., Andersson, A., Semiletov, I., Charkin, A., Dudarev, O., \& Gustafsson, O. (2016). Different sources and degradation state of dissolved, particulate, and sedimentary organic matter along the Eurasian Arctic coastal margin. Global Biogeochemical Cycles, 30(6), 898-919. https://doi.org/10.1002/2015GB005307

\section{Published in:}

Global Biogeochemical Cycles

\section{Citing this paper}

Please note that where the full-text provided on Manchester Research Explorer is the Author Accepted Manuscript or Proof version this may differ from the final Published version. If citing, it is advised that you check and use the publisher's definitive version.

\section{General rights}

Copyright and moral rights for the publications made accessible in the Research Explorer are retained by the authors and/or other copyright owners and it is a condition of accessing publications that users recognise and abide by the legal requirements associated with these rights.

\section{Takedown policy}

If you believe that this document breaches copyright please refer to the University of Manchester's Takedown Procedures [http://man.ac.uk/04Y6Bo] or contact uml.scholarlycommunications@manchester.ac.uk providing relevant details, so we can investigate your claim.

\section{OPEN ACCESS}




\section{Global Biogeochemical Cycles}

\section{RESEARCH ARTICLE}

10.1002/2015GB005307

\section{Key Points:}

- Comparison between dissolved (colloidal), particulate, and sedimentary $O C$ in coastal Arctic

- DOC/COC derived from topsoil OC (65\%), marine OC (25\%), and ICD-OC (9\%)

- OC pools in coastal Arctic may respond on different timescales to climate change

Supporting Information

- Supporting Information S1

- Table S4

- Table S5

Correspondence to:

E. Karlsson,

emmakarlssons@gmail.com

\section{Citation:}

Karlsson, E., J. Gelting, T. Tesi, B. van Dongen, A. Andersson, I. Semiletov, A. Charkin, O. Dudarev, and Ö. Gustafsson (2016), Different sources and degradation state of dissolved, particulate, and sedimentary organic matter along the Eurasian Arctic coastal margin, Global Biogeochem. Cycles, 30, 898-919, doi:10.1002/2015GB005307.

Received 16 OCT 2015 Accepted 27 MAY 2016 Accepted article online 2 JUN 2016 Published online 29 JUN 2016

\section{Different sources and degradation state of dissolved, particulate, and sedimentary organic matter along the Eurasian Arctic coastal margin}

\author{
Emma Karlsson 1,2, Johan Gelting ${ }^{1}$, Tommaso Tesi ${ }^{1,2,3}$, Bart van Dongen ${ }^{4}$, August Andersson ${ }^{1,2}$, \\ Igor Semiletov ${ }^{5,6,7}$, Alexander Charkin ${ }^{5,7}$, Oleg Dudarev ${ }^{5,7}$, and Örjan Gustafsson ${ }^{1,2}$ \\ ${ }^{1}$ Department of Environmental Science and Analytical Chemistry, Stockholm University, Stockholm, Sweden, ${ }^{2}$ Bolin Centre \\ for Climate Research, Stockholm University, Stockholm, Sweden, ${ }^{3}$ Institute of Marine Sciences, ISMAR-CNR, Bologna, Italy, \\ ${ }^{4}$ School of Earth, Atmospheric and Environmental Sciences and Williamson Research Centre for Molecular Environmental \\ Science, University of Manchester, Manchester, UK, ${ }^{5}$ Pacific Oceanological Institute, Russian Academy of Sciences, \\ Vladivostok, Russia, ${ }^{6}$ International Arctic Research Center, University Alaska Fairbanks, Fairbanks, Alaska, USA, ${ }^{7}$ National \\ Research Tomsk Polytechnic University, Tomsk, Russia
}

Abstract Thawing Arctic permafrost causes massive fluvial and erosional releases of dissolved and particulate organic carbon (DOC and POC) to coastal waters. Here we investigate how different sources and degradation of remobilized terrestrial carbon may affect large-scale carbon cycling, by comparing molecular and dual-isotope composition of waterborne high molecular weight DOC ( $>1 \mathrm{kD}$, aka colloidal OC), POC, and sedimentary OC (SOC) across the East Siberian Arctic Shelves. Lignin phenol fingerprints demonstrate a longitudinal trend in relative contribution of terrestrial sources to coastal OC. Wax lipids and cutins were not detected in colloidal organic carbon (COC), in contrast to $\mathrm{POC}$ and $\mathrm{SOC}$, suggesting that different terrestrial carbon pools partition into different aquatic carrier phases. The $\Delta^{14} \mathrm{C}$ signal suggests overwhelmingly contemporary sources for COC, while POC and SOC are dominated by old C from Ice Complex Deposit (ICD) permafrost. Monte Carlo source apportionment $\left(\delta^{13} \mathrm{C}, \Delta^{14} \mathrm{C}\right)$ constrained that $\mathrm{COC}$ was dominated by terrestrial $\mathrm{OC}$ from topsoil permafrost $(65 \%)$ and marine plankton (25\%) with smaller contribution ICD and other older permafrost stocks (9\%). This distribution is likely a result of inherent compositional matrix differences, possibly driven by organomineral associations. Modern OC found suspended in the surface water may be more exposed to degradation, in contrast to older $\mathrm{OC}$ that preferentially settles to the seafloor where it may be degraded on a longer timescale. The different sources which partition into DOC, POC, and SOC appear to have vastly different fates along the Eurasian Arctic coastal margin and may possibly respond on different timescales to climate change.

\section{Introduction}

Thawing of terrestrial organic matter from permafrost in Arctic catchments has the potential to both translocate large stocks of dormant soil carbon to waterborne organic matter and therewith also lead to its conversion to greenhouse gases. Multiple fate processes may affect the previously freeze-locked (permafrost) carbon during lateral translocation, as part of the Arctic Boundless Carbon Cycle [e.g., Vonk and Gustafsson, 2013].

Large quantities of terrestrial organic matter (TerrOM) are delivered to the Eurasian Arctic margin, the largest shelf sea system of the World Ocean. The sources and large-scale biogeochemical cycling of the TerrOM is likely to vary across the climosequence represented by the land-shelf northern margin of the Eurasian continent in response to differences in drainage basin characteristics, climate, and temporal variability [e.g., Stein and MacDonald, 2004; Raymond et al., 2007; van Dongen et al., 2008a, 2008b].

The main terrestrial vectors for TerrOM delivery are river runoff and coastal erosion [e.g., Stein and MacDonald, 2004; Vonk et al., 2012]. Aeolian-driven input is relatively small (Shevchenko and Lizitsin, in Stein and MacDonald [2004]), while subsea groundwater discharge [Aiken et al., 2014] and release of old carbon from degradation of submarine permafrost [Semiletov, 1999; Shakhova et al., 2014; Nicolsky and Shakhova, 2010] are potentially contributing, but are largely unconstrained. Discharge of freshwater to the Arctic is anticipated to increase due to climate change-driven increase in precipitation and in thawing permafrost [Peterson et al., 2002; Serreze et al., 2003; Lyon and Destouni, 2010], which could result in even larger terrestrial OC input to the Eurasian Arctic continental margin. A lengthening of the summer (ice-free) season [Overeem et al., 2011], increased wave fetch [Asplin et al., 2012], and higher temperatures [McGuire et al., 2006; Romanovsky et al., 
2007] may also impact coastal erosion and thereby increase terrestrial matter delivery to the Arctic shelf waters [Lantuit et al., 2012, 2013; McClelland et al., 2012; Sanchez-Garcia et al., 2014].

Earlier studies have shown that different TerrOM pools and matrices have different fate upon remobilization and transport to and in the recipient coastal system. Different TerrOM pools have marked age differences [e.g., Guo et al., 2004; Vonk et al., 2010a; Gustafsson et al., 2011; Karlsson et al., 2011]. There is a stark contrast between the river-borne dissolved organic carbon (DOC), with ${ }^{14} \mathrm{C}$ ages near modern [e.g., Benner et al., 2004; Neff et al., 2006; Guo et al., 2007; Raymond et al., 2007], and the much older fraction of terrestrial OC partitioned into particulate $\mathrm{OC}$ (POC), eventually accumulating preferentially in coastal sediments [e.g., Goni et al., 2005; Vonk et al., 2012; Feng et al., 2015]. Taken together, this suggests strong fractionation among different released $\mathrm{OC}$ pools with a competition between selective preservation and degradation.

The translocated terrestrial-DOC pool, previously thought to mix conservatively in the continental waters of the Eurasian Arctic shelves, has been shown to degrade extensively also in the marine waters [e.g., Alling et al., 2010; Manizza et al., 2009]. DOC has thus been shown to not vary only with salinity over the Eurasian Arctic shelf. POC has also likewise been shown to be efficiently degraded in the water column over large parts of the Eurasian Arctic margin [Sanchez-Garcia et al., 2011] and in similar sub-Arctic systems [van Dongen et al., 2008b]. Mass balance models suggest that POC degrades in the water column at a rate about 5 times faster than the DOC pool; yet, since the DOC pool is about 5-10 times larger than the POC pool [van Dongen et al., 2008b; Sanchez-Garcia et al., 2011], these two vectors may contribute about equally to the $\mathrm{CO}_{2}$ supersaturation observed in these systems [Pipko et al., 2008; Anderson et al., 2009; Semiletov et al., 2012, 2013].

Arctic shelf studies to date have mostly focused on sedimentary or particulate matter characteristics [Fahl and Stein, 1997; Yunker et al., 1996; Vonk et al., 2012], despite DOC being the major carrier of terrestrial organic matter to Eurasian continental margins [Gordeev et al., 1996; Lobbes et al., 2000]. Lobbes et al. [2000] report more than $90 \%$ of total organic carbon (TOC) from Russian rivers to be in dissolved form. The dissolvedcolloidal continuum normally makes up the dominant fraction of water column $\mathrm{OC}$ in coastal waters with large terrestrial export, yet constitutes a less explored compartment [Gustafsson and Gschwend, 1997]. Furthermore, the colloidal fraction $(>1 \mathrm{kD})$ is suggested to become a larger part of the total organic carbon pool in coastal waters in northern latitudes with progressive warming due to a shorter residence time and resulting decreased coagulation and settling in estuarine mixing zones [Pokrovsky et al., 2014].

This study seeks to test the hypothesis that TerrOM released from different sources and transported in different physical forms has different propensity toward both long-range transport and degradation. This paper contributes new data on the high molecular weight (>1 kD) DOC pool (i.e., colloidal OC_colloidal organic carbon (COC)) across the Eurasian Arctic shelf, enabling a more complete comparison with earlier reports on the molecular characteristics of the corresponding POC and SOC pools in the same regimes. The source, composition, and degradation status of $\mathrm{COC}$ and the simultaneously sampled POC and SOC are investigated outside five major Eurasian Arctic Rivers. The collection of samples across the longitudinal extent of the northern Eurasian Arctic seaboard is investigated through dual isotopes of carbon and several classes of biomarkers (e.g., solvent-extractable lipids and $\mathrm{CuO}$ oxidation products).

\section{Background}

\subsection{Study Area}

The Eurasian Arctic Shelf is the largest, yet, shallowest continental shelf system of the World Ocean. Ob and Yenisey in the west discharge the west Siberian wetlands to the Kara Sea. The Lena River drains both regions of sporadic permafrost and boreal forests in the south to continuous permafrost in the north, into the Laptev Sea. Indigirka and Kolyma run entirely through continuous permafrost of the East Siberian highlands to the East Siberian Sea (Figure 1). Several thousand kilometers of the Eurasian Arctic coastline are rich in permafrost ice wedges and vulnerable to erosion [Grigoriev et al., 2006; Lantuit et al., 2012; Günther et al., 2013]. Günther et al. [2013] presents an overview of studies of thermo-eroding coasts, which have been subject for study since far back [e.g., Kaplina, 1959], but the harsh winter conditions with ice cover around 9-10 months/year and temperatures below $-40^{\circ} \mathrm{C}$ have restricted this research. Despite considerable freshwater discharge [Aagaard and Carmack, 1989], several studies suggest a large part of the terrestrial OC in the East Siberian Arctic Shelf (ESAS) surface sediments to be derived from coastal erosion of the Pleistocene Ice Complex 

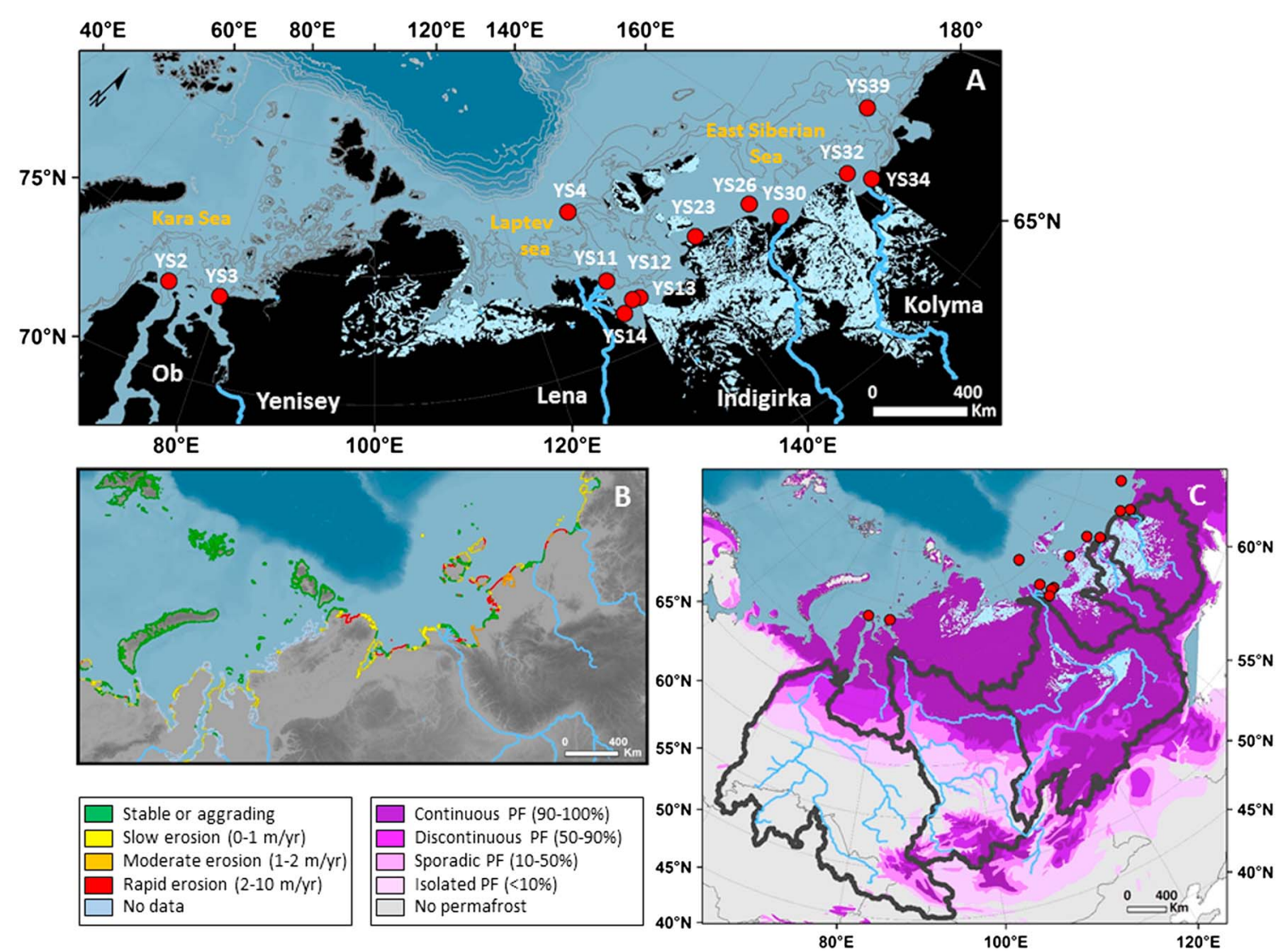

Figure 1. (a) Map of the Eurasian Arctic shelf with land area in black, yedoma/mineral soil/ICD-OC in light blue/grey outline, and major rivers in blue. (b) Coastal erosion rates [from Lantuit et al., 2012]. (c) Permafrost coverage of the Eurasian Arctic, watersheds outlined in black [Brown et al., 2014]. Exact location and characteristics of sampling stations (red circles) are given in the supporting information.

Deposits (ICD-OC, aka Yedoma [Rachold et al., 2000; Vonk et al., 2012; Shakhova et al., 2009a, 2009b]). The origin of the ICD is debated and includes both fluvial sources and aeolian loess deposition [e.g., Schirrmeister et al., 2013]. The situation is different in the western catchments of Ob and Yenisey, which are milder with winter temperatures around $-20^{\circ} \mathrm{C}$. These western regions do not contain any ICD-OC but instead store large permafrost peat deposits. Also, the sharp spring flood typical for the Eurasian Arctic Rivers is logistically challenging for field studies seeking to quantify the actual terrestrial carbon release, especially for DOC [Holmes et al., 2002, 2012; Spencer et al., 2008].

The Eurasian Arctic Rivers serve as integrators of their drainage basin characteristics, such as vegetation and permafrost coverage (detailed in supporting information Text $\mathrm{S} 1$ ), which determines the composition of the released organic matter [Cauwet and Sidorov, 1996; Stein et al., 2003; Bianchi and Allison, 2009]. These source characteristics can be investigated using biomarkers and other conserved tracers. Despite the dominance of the Lena River discharge leaving a major trace through its eastward direction of flow, different imprints have been observed and associated to east-westerly gradients over the Eurasian Arctic continent [van Dongen et al., 2008a; Gustafsson et al., 2011; Tesi et al., 2014]. Thus, the different river inputs along the ESAS coast are not resolvable with variations in salinity only, as riverine inputs have nearly the same salinity. The rivers' characteristics are better separated spatially, on a surface map, or as presented in this paper, versus longitude.

\subsection{Temporal Perspectives}

The observed TerrOM signals may be affected by both seasonal and interannual variability as well as proximity to the terrestrial source of the various shelf stations. In a study of a (sub)-Arctic estuary, the majority of the colloidal carbon discharge was reported to happen during the spring flood [Pokrovsky et al., 2010], which is in concurrence with the largest fraction of the annual DOC and POC discharges [Cauwet and 
Sidorov, 1996]. Most Arctic Rivers have a documented sharp and short spring flood carrying a major part of the annual DOC, POC, and suspended sediment load [Gordeev et al., 1996; Holmes et al., 2002; Raymond et al., 2007]. The spring flood also brings a different carbon pool than the late summer discharge. Spring flush happens at the onset of warming when the upper layers are still frozen giving a predominance of surface litter and leaching of shallow soil layers [Guo and Macdonald, 2006; Neff et al., 2006; Frey and McClelland, 2009]. DOC discharged in late summer exhibits lower (carbon normalized) lignin yields, lesser degree of high molecular weight (HMW) aromaticity, and a smaller influence of organic-rich upper soil horizons than the spring flood [Striegl et al., 2005, 2007; Spencer et al., 2008].

The COC and the simultaneously sampled POC and SOC of this study were collected in the end of the summer season, during late July to early September, which generally is the midwater season. Our stations are representations of OC source apportionment in the coastal ocean. The signals are integrated over longer timescales than the faster episodic events in the rivers and the carbon source partitioning zone. Variations in river outflow give rise to temporally varying concentrations over the summer season at any single sampling station. The late summer season is when the permafrost active layer is at its deepest during the year, which gives a stronger signal from the deeper conduits and a stronger groundwater influence. Some of the current data set may thus reflect a somewhat different pool of carbon than the more labile spring freshet OC [Cooper et al., 2005; Mann et al., 2012; Vonk et al., 2013]. The year of sampling (2008) experienced especially high Lena River discharge, with elevated levels of river runoff also later in the open water season [Charkin et al., 2011]. Average annual discharge between 1998 and 2008 was $588 \mathrm{~km}^{3} / \mathrm{yr}^{\mathrm{r}}$ [Holmes et al., 2012: earlier estimate, between 1965 and 1995, $520 \mathrm{~km}^{3} / \mathrm{yr}$, Rachold et al., 1996], and in 2008 it was $716 \mathrm{~km}^{3}$ [Charkin et al., 2011]. However, as mentioned above, many of our 2008 observations on the shelf were not positioned directly by a river mouth but further offshore. These stations represent continental shelf water masses (with residence times on the shelf on the order of a year, e.g., Manizza et al. [2009], Bauch et al. [2009], and Alling et al. [2010]), which thus would integrate suspended OC load from throughout the season.

\section{Materials and Methods}

\subsection{Sampling}

The samples were collected as part of the International Siberian Shelf Study (ISSS) 2008 (ISSS-08) on board H/V Yakob Smirnitsky [Semiletov and Gustafsson, 2009]. Samples for high-volume cross-flow filtration (CFF) for subsequent molecular and isotopic characterization were taken outside the largest rivers of the Eurasian Arctic, from coastal erosion hot spots and from additional stations across the ESAS (Figure 1). The total sample collection thus consisted of four types of samples (Table 1): (i) colloidal organic carbon (COC) isolated with CFF ( $1 \mathrm{kD}$ cutoff), (ii) DOC, the filtrate of $<0.7 \mu \mathrm{m}$, (iii) the POC from high-volume filtration on GF/F filters with a nominal $0.7 \mu \mathrm{m}$ cutoff, and (iv) SOC from surface sediments $(0-2 \mathrm{~cm}$ ) from Van Veen grab samples (the top $2 \mathrm{~cm}$ was carefully subsampled from grab sample surface sediment with stainless steel spatulas). Sampling of COC was carried out via seawater intake during many hours of transit (see Table S1 for sampling details). Collection of DOC, POC, and SOC was carried out at discrete locations and times.

This study is the first to compare both the COC, POC, and SOC fractions for both solvent-extractable (plant wax) lipid biomarkers, $\mathrm{CuO}$ oxidation reaction product (e.g., lignin phenol) biomarkers, and bulk geochemical properties (elemental ratios, stable, and radiocarbon isotopes). Some of the POC and SOC data in this comparison have been published earlier-the details of this are given in the supporting information Text S2.

\subsubsection{Cross-Flow Filtration (CFF)}

\subsubsection{The CFF System and Operation}

Prefiltered seawater (over precombusted GF/F filters held in a stainless steel holder) was concentrated over a Millipore ${ }^{\oplus}$ Pellicon 2 system with two CFF filter cartridges $\left(0.5 \mathrm{~m}^{2}\right.$ regenerated cellulose membranes of $\left.<1 \mathrm{kD}\right)$ to around $1 \mathrm{~L}$ (concentration factors between 77 and 120; well above the recommended value of 10) largely following previously established Millipore Pellicon 2 CFF protocols [Larsson et al., 2002]. The system had precombusted glass parts, silicon tubing, and was circulated with a flow-jet pump. An average retentate flow of 2.9 to $6.5 \mathrm{~L} / \mathrm{min}$ (with transmembrane pressures between 1-2 bar) and a permeate flow between 110 and $160 \mathrm{~mL} / \mathrm{min}$ were maintained during the filtration (i.e., cross-flow ratios well above the recommended 15; 
Table 1. Bulk Parameters of Surface Water Colloidal, Surface Water Particulate, and Surface Sediment Organic Matter Samples From the East Siberian Arctic Shelf ${ }^{a}$

\begin{tabular}{|c|c|c|c|c|c|c|c|c|c|c|c|}
\hline Station & $\begin{array}{l}\text { Latitude } \\
\qquad\left({ }^{\circ} \mathrm{N}\right)\end{array}$ & $\begin{array}{l}\text { Longitude } \\
\left({ }^{\circ} \mathrm{E}\right)\end{array}$ & $\begin{array}{c}\text { Dominant } \\
\text { Catchment Influence }\end{array}$ & $\begin{array}{c}\text { Nearest } \\
\text { Major River }\end{array}$ & Salinity & $\begin{array}{c}\text { Distance } \\
\text { to Coast }(\mathrm{km})\end{array}$ & $\begin{array}{l}\text { Sampling } \\
\text { Depth (m) }\end{array}$ & OC (\%) & $\delta 13 C(\% \circ)$ & $\Delta 14 \mathrm{C}(\% \mathrm{o})$ & $\mathrm{Fm}$ \\
\hline \multicolumn{12}{|c|}{ Colloidal OC } \\
\hline YS2 & 73.4 & 73.0 & WSL & 0 & 7.88 & 48 & 4 & 26.9 & -28.2 & -10.8 & 1.00 \\
\hline YS3 & 73.5 & 79.9 & WSL & $Y$ & 4.86 & 9 & 4 & 20.4 & -27.7 & 75.2 & 1.08 \\
\hline YS4 & 76.0 & 130.0 & CSP & $\mathrm{L}$ & 12.3 & 160 & 3 & 6.17 & -27.4 & 44.3 & 1.05 \\
\hline YS11 & 73.0 & 130.0 & CSP & $\mathrm{L}$ & 2.04 & 27 & 3 & 23.7 & -27.8 & 49.7 & 1.06 \\
\hline YS12 & 71.9 & 132.6 & CSP & $\mathrm{L}$ & 25.0 & 2 & 4 & 14.4 & -27.1 & 3.46 & 1.01 \\
\hline YS14 & 71.6 & 130.0 & CSP & $\mathrm{L}$ & 1.06 & 22 & 4 & 23.7 & -27.7 & 55.1 & 1.06 \\
\hline YS23 & 72.8 & 142.7 & CSP & $\mathrm{L}$ & 12.2 & 10 & 2,5 & 20.2 & -27.7 & -22.1 & 0.98 \\
\hline YS26 & 72.5 & 150.6 & $\mathrm{ESH}$ & I & 19.2 & 48 & 4 & 14.5 & -27.3 & -41.8 & 0.96 \\
\hline YS30 & 71.4 & 152.2 & ESH & I & 18.2 & 19 & 3 & 14.8 & -27.8 & -39.7 & 0.97 \\
\hline YS32 & 70.6 & 161.2 & $\mathrm{ESH}$ & K & 25.4 & 26 & 3 & 9.50 & -26.4 & -84.0 & 0.92 \\
\hline YS34B & 69.8 & 162.3 & $\mathrm{ESH}$ & K & 24.6 & 12 & 1 & 12.7 & -26.8 & -65.7 & 0.94 \\
\hline YS39 & 71.2 & 169.4 & ESH & K & 27.6 & 140 & 4 & 6.78 & -23.9 & -106 & 0.90 \\
\hline \multicolumn{12}{|c|}{ Particulate OC } \\
\hline YS2 & 73.41 & 73.00 & WSL & $\mathrm{O}$ & 7.88 & 48 & 2 & 113 & -28.7 & -32 & 0.98 \\
\hline YS3 & 73.49 & 79.89 & WSL & $Y$ & 4.86 & 9 & 4 & 96.6 & -27.8 & -6.3 & 1.00 \\
\hline YS4 & 75.99 & 129.98 & CSP & $\mathrm{L}$ & 13.3 & 160 & 4 & 89.2 & -30.2 & -75.4 & 0.93 \\
\hline YS11 & 73.02 & 129.99 & CSP & $\mathrm{L}$ & 2.23 & 27 & 2 & 626 & -27.4 & -202 & 0.80 \\
\hline YS12 & 71.92 & 132.58 & CSP & $\mathrm{L}$ & 25.0 & 2 & 2 & 319 & -27.8 & - & - \\
\hline YS14 & 71.63 & 130.05 & CSP & $\mathrm{L}$ & 0.98 & 22 & 2 & 1050 & -27.1 & -374 & 0.63 \\
\hline YS23 & 72.79 & 142.67 & CSP & $\mathrm{L}$ & 12.1 & 10 & 2 & 170 & -29.2 & - & - \\
\hline YS26 & 72.46 & 150.60 & ESH & I & 19.2 & 48 & 2 & 62.9 & -30.1 & -289 & 0.72 \\
\hline YS30 & 71.36 & 152.15 & ESH & i & 19.3 & 19 & 2 & 178 & -28.1 & -89 & 0.92 \\
\hline YS32 & 70.57 & 161.22 & ESH & $\mathrm{K}$ & 24.9 & 26 & 2 & 188 & -28.8 & - & - \\
\hline YS34B & 69.76 & 162.32 & $\mathrm{ESH}$ & $\mathrm{K}$ & 23.8 & 12 & 1 & 186 & -28.7 & -75.0 & 0.93 \\
\hline YS39 & 71.22 & 169.37 & ESH & $\mathrm{K}$ & 27.6 & 140 & 4 & 54.1 & -23.4 & -37.4 & 0.97 \\
\hline \multicolumn{12}{|c|}{ Sediment OC } \\
\hline YS2 & 73.41 & 73.00 & WSL & $\mathrm{O}$ & 29.8 & 48 & 49.3 & 1.25 & -27.4 & -220 & 0.785 \\
\hline YS3 & 73.49 & 79.89 & WSL & $Y$ & 32.7 & 9 & 9.2 & 1.96 & -26.9 & -216 & 0.790 \\
\hline YS4 & 75.99 & 129.98 & CSP & $\mathrm{L}$ & 33.2 & 160 & 163 & 1.44 & -25.0 & -437 & 0.567 \\
\hline YS11 & 73.02 & 129.99 & CSP & $\mathrm{L}$ & 26.1 & 27 & 28.0 & 1.93 & -26.6 & - & - \\
\hline YS12 & 71.92 & 132.58 & CSP & $\mathrm{L}$ & 26.8 & 2 & 2.1 & 0.35 & - & - & - \\
\hline YS14 & 71.63 & 130.05 & CSP & $\mathrm{L}$ & 1.30 & 22 & 22.0 & 1.91 & -26.2 & -504 & 0.499 \\
\hline YS23 & 72.79 & 142.67 & CSP & $\mathrm{L}$ & 17.3 & 10 & 10.3 & 0.91 & -27.2 & -691 & 0.312 \\
\hline YS26 & 72.46 & 150.60 & $\mathrm{ESH}$ & I & 27.1 & 48 & 48.5 & 0.87 & -27.4 & -741 & 0.261 \\
\hline YS30 & 71.36 & 152.15 & ESH & I & 22.9 & 19 & 19.5 & 1.35 & -27.4 & -682 & 0.320 \\
\hline YS32 & 70.57 & 161.22 & ESH & $\mathrm{K}$ & 28.5 & 26 & 26.4 & 0.42 & -26.4 & - & - \\
\hline YS34B & 69.76 & 162.32 & ESH & $\mathrm{K}$ & 29.9 & 12 & 11.8 & 1.12 & -27.3 & -554 & 0.449 \\
\hline YS39 & 71.22 & 169.37 & ESH & $\mathrm{K}$ & 32.4 & 140 & 138 & 1.23 & -24.3 & - & - \\
\hline
\end{tabular}

${ }^{a}$ Latitude $\left({ }^{\circ} \mathrm{N}\right)$, longitude $\left({ }^{\circ} \mathrm{E}\right)$, salinity, approximate distance to the nearest coast $(\mathrm{km})$, sampling depth $(\mathrm{m})$ or water column depth $(\mathrm{m})$, organic carbon content $\mathrm{OC}(\%), \delta 13 \mathrm{C}(\%), \Delta 14 \mathrm{C}(\%)$, and fraction modern. Dominant catchment influence refers to West Siberian Lowlands (WSL), Central Siberian Plateau (CSP), and East Siberian Highlands (ESH). Nearest major rivers are denoted with O for Ob, Y for Yenisey, L for Lena, I for Indigirka, and K for Kolyma.

Larsson et al. [2002]). The system was cleaned between samples as described below, and samples were stored frozen in prerinsed polycarbonate bottles at $-20^{\circ} \mathrm{C}$. Concentrations of the different fractions and CFF recoveries are detailed in the supporting information (Table S1).

\subsubsection{CFF Cleaning and Preparation Procedure}

Prior to use, the CFF Pellicon 2 filters were subject to cleaning procedures following both Millipore ${ }^{\circledR}$ recommendations and previous tests in the laboratory [Larsson et al., 2002]. Filters were washed with $20 \mathrm{~L}$ MilliQ water, $5 \mathrm{~L}$ of $\mathrm{NaOH}$ of $\mathrm{pH} 11,5 \mathrm{~L}$ of MilliQ water, $5 \mathrm{~L}$ of $\mathrm{HCl} \mathrm{pH3}$, and then MilliQ water until the permeate reached neutral $\mathrm{pH}$. Filters were then stored in $0.1 \mathrm{M} \mathrm{H}_{3} \mathrm{PO}_{4}$ before use. Between the sampling sites YS2 and YS30, the filters were cleaned with $5 \mathrm{~L}$ of $\mathrm{NaOH}$ pH 11, $5 \mathrm{~L}$ permeate from the previous station $(<1 \mathrm{kDa}), 5 \mathrm{~L}$ of $\mathrm{HCl} \mathrm{pH} 3$, and $5 \mathrm{~L}$ of permeate. However, before the last stations, the shipboard MilliQ had a failure, and we had to reduce the use of MilliQ water. In between YS30, YS34, YS37, and YS39 we therefore used only $3 \mathrm{~L} \mathrm{NaOH}$, and the acid was diluted in permeate from the innermost Lena transect station (water with salinity of 1 ). 


\subsubsection{Desalting and Freeze Drying}

The samples were desalted using the same CFF system setup but running each sample over a large amount of MilliQ water in diafiltration mode prior to chemical analyses. Frozen COC field samples were thawed in a refrigerator, and half of the total quantity was desalted by using a fresh and cleaned $1 \mathrm{kD}$ Millipore Pellicon 2 filter in the laboratory. The volume of MilliQ water ranged from 6 to $17 \mathrm{~L}$ between samples, as it was adjusted to sample salt content. The recovery of $\mathrm{COC}$ for the desalting procedure ranged between 0.66 and 1.1 (mean 0.8 ), which means that generally $20 \%$ of the COC material was lost during work-up. Total blank contribution was estimated to $50 \mu \mathrm{M}$, at the most $4 \%$ of the OC in the samples. More details and recovery parameters for sampling and laboratory processing are given in Table S1.

The COC samples were dried in polycarbonate bottles under vacuum in a low-carbon-background freeze drier (Christ Alpha 2-4, LSC; Vacuum hybrid pump, Vacubrand RC-6; and Martin Christ, Labex Instrument $A B)$. The dried material was scraped with a stainless steel spatula from the flask, weighed, and stored in a freezer for chemical and isotopic analyses. Similarly, SOC was freeze dried in polypropylene containers, POC on GF/F filters, and both subsampled for further analysis.

\subsection{Biomarkers}

\subsubsection{Solvent Extraction of Wax Lipids}

Extraction and work-up procedures for POC and SOC of solvent-extractable wax lipids have been detailed earlier in, e.g., van Dongen et al. [2008a, 2008b]. Briefly, lipid fractions from freeze-dried POC and SOC ( 3 g $\mathrm{dw}$ ) were retrieved using Soxhlet extraction in dichloromethane:methanol, DCM:MeOH, (2:1 vol/vol, $24 \mathrm{~h})$, separated through Bond Elut ${ }^{\oplus}$ (SP: $\mathrm{NH}_{2}$ ) and $\mathrm{Al}_{2} \mathrm{O}_{3}$ column chromatography. Isolation of $\mathrm{COC}$ lipid fractions was done without separation of the total lipid extracts due to small sample sizes. Amounts equivalent of $0.50 \mathrm{mg} \mathrm{OC}$ of the freeze-dried homogenized samples were weighed into round flasks and extracted through $24 \mathrm{~h}$ reflux in $30 \mathrm{~mL}$ DCM:MeOH (2:1 volumetric ratio). The total lipid extract was run through a $\mathrm{Na}_{2} \mathrm{SO}_{4}$ (anhydrous) column for separation of solids and removal of water. Hydrocarbon fractions were eluted through (10\% deactivated) silica columns prior to gas chromatography-mass spectrometry (GC-MS) analysis. No significant contaminations of target analytes were recorded, and standards were used for quantification, calibration, and recovery calculations (D50-tetracosane, D39-eicosanoic acid, 2-hexadecanol, and D10-Pyrene). Blank corrections have been used. Five of the $n$-alkane and $n$-alkanoic acid data points for POC and SOC used in this study have been previously published (POC and SOC from YS34B, YS39 in Vonk et al. [2010a, 2010b], and POC of YS14 in Sanchéz-García et al. [2011]).

\subsubsection{Alkaline CuO Oxidation Extraction of Lignin and Hydroxy Phenols}

Between 1 and $2 \mathrm{mg} O C$ equivalent of the freeze-dried homogenized colloidal matter samples was subjected to alkaline $\mathrm{CuO}$ oxidation for release of lignin and hydroxyl phenols under pressure and heating to $80^{\circ} \mathrm{C}$ in a microwave system following Goni and Montgomery [2000], with an addition of 1 mg glucose to avoid superoxidation [Louchouarn et al., 2000]. Procedure used for alkaline CuO oxidation is described in detail in Tesi et al. [2014], from which also the CuO oxidation reaction products for the corresponding sediment samples in this study are reported. POC in this sample collection was sampled on GF/F filters that are not compatible with the alkaline hydrolysis of the $\mathrm{CuO}$ oxidation protocol.

\subsubsection{Instrumental Analysis of Biomarkers}

Biomarker concentrations for the different fractions of $\mathrm{COC}$ and the complementary POC and SOC samples were quantified using an Agilent GC/MS with an on-column injector. Compounds were separated chromatographically on a fused silica capillary column ( $30 \mathrm{~m} \times 250 \mu \mathrm{m}$ DB5-MS, film thickness $0.25 \mu \mathrm{m}$, Agilent J\&W) with helium as carrier gas. The initial oven temperature was $60^{\circ} \mathrm{C}$ and was ramped to $300^{\circ} \mathrm{C}$ at $4{ }^{\circ} \mathrm{C} / \mathrm{min}$. Mass scanning was done between $\mathrm{m} / \mathrm{z}$ of $50-600$ at $70 \mathrm{eV}$. Extracts were derivatized with bis-trimethylsilyltrifluoroacetamide $+1 \%$ trimethylchlorosilane to silylate exchangeable hydrogen prior to the injection for $n$-alkanoic acids, $n$-alkanols, and for CuO oxidation reaction products.

\subsection{Carbon Isotopes}

Freeze-dried homogenized, ground colloidal matter samples (130-890 $\mu \mathrm{g} \mathrm{OC)} \mathrm{were} \mathrm{weighed} \mathrm{into} \mathrm{precom-}$ busted silver capsules $(5 \times 9 \mathrm{~mm}$, Säntis Analytical AG, Teufen, Switzerland) and twice acidified with $50 \mu \mathrm{L}$ $1 \mathrm{M} \mathrm{HCl}$ for removal of dissolved inorganic carbon (DIC), dried $3 \mathrm{~h} \mathrm{in} 50^{\circ} \mathrm{C}$, and sent to National Ocean Sciences Facility for Accelerator Mass Spectrometry at Woods Hole Oceanographic Institution (Woods Hole, $\mathrm{MA}$, USA) for ${ }^{14} \mathrm{C}$ analysis. Samples for stable carbon isotope analysis were similarly pretreated through 
acidification and drying in silver capsules and processed at the Stable Isotope Laboratory (SIL) at Stockholm University (Department of Geological Sciences) with a Carlo Erba NC2500 elemental analyzer connected via a split interface to a Finnigan MAT Delta Plus mass spectrometer.

\subsection{TOC and DOC}

Analysis of TOC and DOC concentrations has been detailed in Alling et al. [2010]. The bulk organic carbon components were separated into POC ( $>0.7 \mathrm{~mm}$ GF/F filters; Whatman, Inc.), DOC (GF/F filtrate), and TOC (unfiltered). The 1-3 $\mathrm{L}$ seawater samples were vacuum-filtered onboard with $25 \mathrm{~mm}$ diameter precombusted filters within an all-glass filtration system [Sanchez-Garcia et al., 2011]. The samples were kept in $60 \mathrm{~mL}$ Nalgene high-density polyethylene bottles and measured directly onboard. The DOC and TOC analyses were done by high-temperature catalytic oxidation (Shimadzu TOC-VCPH). Inorganic carbon was removed by acidifying the samples to $\mathrm{pH} 2$ by $2 \mathrm{M} \mathrm{HCl}$ and sparging for $8 \mathrm{~min}$ prior to analysis of the total carbon content. All procedures for calibration and data analysis followed Sharp et al. [1995]. Consensus Reference Materials (CRM, from University of Miami) of low-carbon content (1-2 mM C) and deep-sea reference water (41-44 mM C) was run prior to each analysis batch. Our results throughout the expedition for the deep-sea reference water were $42.3 \pm 3.4 \mathrm{mM}(n=15)$. Additionally, an internal control sample from the Yenisey estuary (DOC $494 \pm 23 \mathrm{mM})$ was run in duplicate after every 10 samples to monitor drift or interruptions during the run. New calibrations were made when the results of the CRM or the internal control samples differed from known concentrations by more than $\sim 5 \%$. Each sample was run in five replicate injections. The overall precision of the measurements was generally better than $5 \%$ ( $85 \%$ of data set). For samples with $<80 \mathrm{mM} \mathrm{DOC}$, from the outer shelf and deep waters, the precision was $\sim 8 \%$. CFF retentate samples were diluted with MilliQ and measured on the Shimadzu TOC Analyzer.

\subsection{Monte Carlo Simulations}

The relative contribution of the three carbon source classes (topsoil OC, Ice Complex Deposit ICD-OC, and marine plankton $O C)$ to each sample was assessed in a dual-carbon isotope $\left(\delta^{13} C\right.$ and $\left.\Delta^{14} C\right)$ end-member mixing model analysis. To incorporate the variability of each end-member into the resulting source fractions, a Monte Carlo (MC) computer simulation approach was applied [Andersson, 2011]. Each value (both endmember and observational data point) was represented by a normal distribution instead of a single value. The modeling included a repeated random sampling strategy of $10^{6}$ iterations per sample that discard source contributions outside the physical range $([0,1])$. The model was run in Matlab, version 2013b (Mathworks Inc., Natick, USA). The input end-member parameters can be found in Table 3 with definition/selection criteria described below and with end-member databases in the supporting information Tables S3 and S4.

The first end-member represented in the source apportionment was defined as the integrated signal from active layer $\mathrm{OC}$ and fresh vegetation debris brought by rivers and erosion to the shelf system. This end-member, which we denote as the topsoil OC end-member, has here been revised from what was used in, e.g., Vonk et al. [2012], updated and split into two separate end-members-one for the part of the topsoil OC carried in the dissolved phase and one for the part carried in the particulate phase. The end-member data are shown in the supporting information Tables S3 and S4. This subdivision is motivated by observations of a stark age decoupling between riverine DOC and riverine POC (shift of 164\%o). The topsoil OC end-member for DOC (Table 3) is based on 20 observations of $\delta^{13} \mathrm{C}$-DOC and 20 observations of $\Delta^{14} \mathrm{C}$-DOC values from the Lena and Kolyma Rivers (e.g., data from the programs PARTNERS and Arctic-GRO [Neff et al., 2006]). The topsoil end-member for POC (Table 3) was based on $137 \delta^{13} \mathrm{C}$ and 17 riverine $\Delta^{14} \mathrm{C}$-POC measurements from sites that are not (or minimally) draining ICD soils: in the rivers Lena, Khatanga, Yana, Kolyma, and Panteleikha (data from Rachold and Hubberten [1999]; PARTNERS project; Arctic-GRO; and unpublished data from Lena River). The riverine POC signal could be influenced by freshwater plankton OC, which can vary considerably [Goering et al., 1990; Gu et al., 1994; Kling et al., 1992; Rachold and Hubberten, 1999; Galimov et al., 2006; Winterfeld et al., 2015].

The ICD-OC end-member database was identical to what was used by Vonk et al. [2012] for the ESAS (Table 1). The catchments of $\mathrm{Ob}$ and Yenisey, draining into the Kara Sea, hold no ICD. The $\Delta^{14} \mathrm{C}$ of older soil and permafrost deposits of the $\mathrm{Ob}$ and Yenisey catchments, characterized by discontinuous permafrost, are instead represented by catchment-specific values of 225 peat basal age values from MacDonald et al. [2006] (supporting information Table S5). In addition, old ${ }^{14} \mathrm{C}$ ages of terrestrial biomarkers at the mouths of the Ob and 

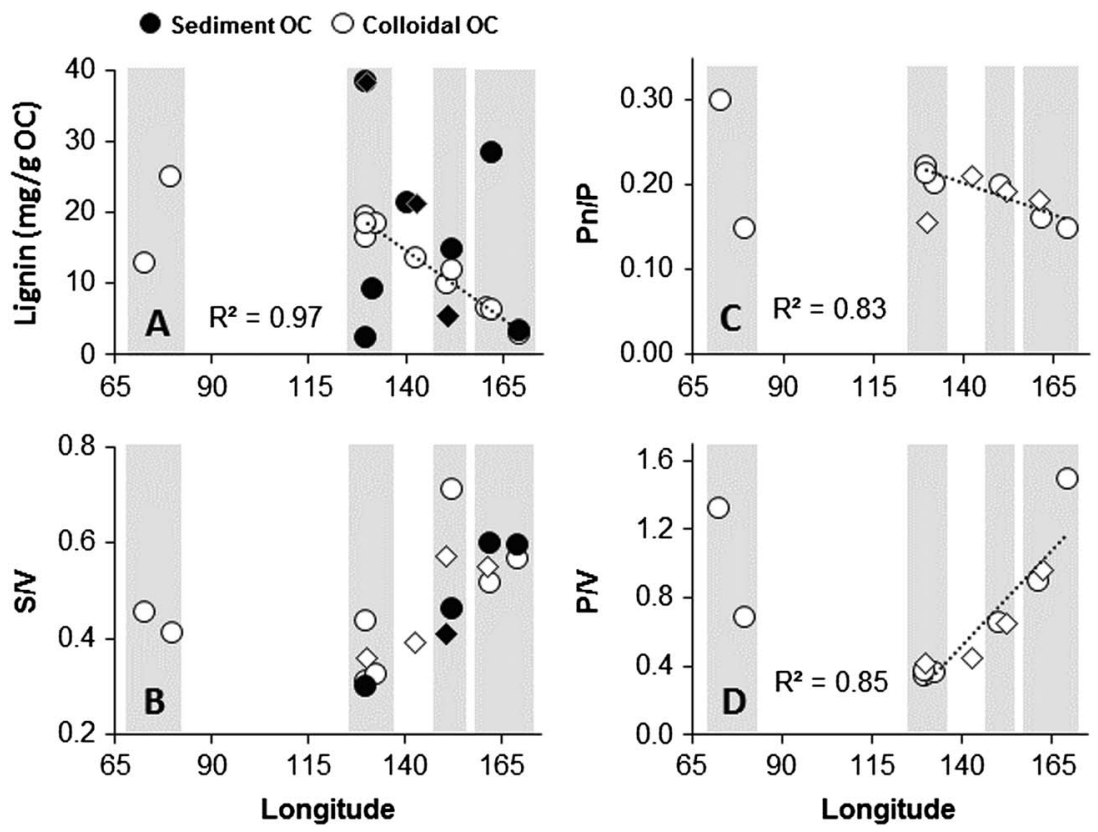

Figure 2. Molecular source proxies in two carbon pools over the Eurasian Arctic margin. Surface water colloidal organic carbon (COC, white circles) and surface sediment organic carbon (SOC, black circles) from July to August 2008. CuO oxidation reaction product-based proxies: (a) Lignin phenol concentration, sum of eight lignin phenol monomers in $\mathrm{mg} / \mathrm{g}$ OC. (b) Angiosperm plant matter proxy and syringyl phenols over vanillyl phenols. (c) Proxy for Sphagnum-sourced p-hydroxyacetophenone (Pn) over p-hydroxybenzoic acids (P), Pn/P. (d) Tracer of marine versus Sphagnum-derived matter, P/V. Shaded bars indicate area of major river outflows, from left to right: Ob plus Yenisey, Lena, Indigirka, and Kolyma. Erosion hot spot stations are denoted as diamonds.

Yenisey Rivers are possibly representing OC from deeper hydraulic conduits of higher hydraulic conductivity than through the peat itself [Gustafsson et al., 2011; Feng et al., 2013]. These deep peat deposits were represented with the same $\delta^{13} \mathrm{C}$ values as the topsoil end-member since there is a high OC preservation potential through the peat column and little or no anticipated fractionation (Table 3).

The marine end-member is also identical to what was reported in Vonk et al. [2012] for the ESAS (Table 3). There is, however, a biogeochemical shift in both water column and sedimentary imprint approximately over the geographical $165^{\circ}$ E longitude [Semiletov et al., 2005; Pipko et al., 2008; Anderson et al., 2009], which reflects the Pacific inflow from the east. These different regimes are thus represented with two different endmembers. The end-member value for the marine planktonic source west of $165^{\circ} \mathrm{E}$ (Table 3 ) is less depleted and likely influenced by assimilated terrestrial OC-derived DIC [Pipko et al., 2008; Anderson et al., 2009; Alling et al., 2010]. The three-source end-members are represented by six values (but only three were used to model each data point), where (i) topsoil DOC is separated from topsoil POC/SOC, (ii) marine contribution is represented by two geographical areas-east and west of $165^{\circ} \mathrm{E}$, and (iii) old permafrost deposits are divided by two geographical areas where one represents deep permafrost OC (deep PF-OC) for Ob and Yenisey catchments and one ICD-OC over the ESAS (Figure S1). The data compilation for calculating all end-member values that are not reported earlier can be found in the supporting information (Tables S3-S5).

\section{Results and Discussion}

\subsection{Source-Diagnostic Composition of COC Versus POC and SOC}

\subsubsection{Molecular Biomarkers-CuO Oxidation Products and Plant Wax Lipids}

Lignin is a phenolic biopolymer exclusively produced by vascular plants [Sarkanen and Ludwig, 1971] and therefore also a common tracer of different sources of terrestrial matter in marine sediments [Goni et al., 2013; Pasqual et al., 2011]. The lignin content of COC, normalized to organic carbon, was on the same order as reported values in the corresponding underlying ESAS sediments. Lignin content in the COC ranged from 3 to $25 \mathrm{mg} / \mathrm{g}$ OC (Figure 2a and Table 2). There was a strong trend of increasing lignin content toward the western catchments releasing to the Laptev Sea/East Siberian Sea (linear regression, $r^{2}=0.97, p<0.001$ ). 
Table 2. Source Proxies of Surface Water Colloidal, Surface Water Particulate, and Surface Sediment Organic Matter Samples From the East Siberian Arctic Shelf ${ }^{\mathrm{a}}$

\begin{tabular}{|c|c|c|c|c|c|c|c|c|c|c|c|c|}
\hline \multicolumn{6}{|c|}{ Colloidal OC } & \multicolumn{2}{|c|}{ Particulate OC } & \multicolumn{5}{|c|}{ Sediment OC } \\
\hline Station & $\begin{array}{c}\text { Lignin } \\
\text { (mg/g OC) }\end{array}$ & $\mathrm{C} / \mathrm{V}$ & $\mathrm{S} / \mathrm{V}$ & $\mathrm{Pn} / \mathrm{P}$ & $\mathrm{P} / \mathrm{V}$ & $\begin{array}{c}\text { HMW lipids } \\
\text { (mg/g OC) }\end{array}$ & $\begin{array}{c}\text { HMW/LMW } \\
n \text {-alks }\end{array}$ & $\begin{array}{l}\text { HMW lipids } \\
\text { (mg/g OC) }\end{array}$ & $\begin{array}{c}\text { HMW/LMW } \\
n \text {-alks }\end{array}$ & $\begin{array}{c}\text { Lignin } \\
\text { (mg/g OC) }\end{array}$ & $\mathrm{C} / \mathrm{V}$ & $\mathrm{S} / \mathrm{V}$ \\
\hline YS2 & 12.7 & 0.14 & 0.45 & 0.30 & 1.64 & - & 0.15 & 0.88 & 185 & - & - & - \\
\hline YS3 & 24.9 & 0.11 & 0.41 & 0.15 & 0.42 & - & 0.11 & 0.68 & 78 & - & - & - \\
\hline YS4 & 19.4 & 0.09 & 0.31 & 0.16 & 0.34 & 0.14 & 2.41 & 0.39 & 41 & 2.4 & 0.2 & 0.3 \\
\hline YS11 & 16.4 & 0.12 & 0.43 & 0.22 & 0.42 & 0.08 & 2.50 & 0.92 & 58 & - & - & - \\
\hline YS12 & 18.3 & 0.07 & 0.32 & 0.20 & 0.35 & 0.11 & 5.01 & 0.53 & 175 & - & - & - \\
\hline YS14 & 18.3 & 0.10 & 0.36 & 0.21 & 0.37 & - & 0.21 & 0.86 & 59 & 38.2 & 0.18 & 0.62 \\
\hline YS23 & 13.6 & 0.04 & 0.39 & 0.21 & 0.45 & 0.07 & 19.5 & 1.37 & 9.7 & 21.4 & 0.04 & 0.46 \\
\hline YS26 & 9.8 & 0.14 & 0.57 & 0.20 & 0.65 & 0.11 & 9.95 & 1.46 & 8.1 & 5.5 & 0.0 & 0.4 \\
\hline YS30 & 11.7 & 0.13 & 0.71 & 0.19 & 0.65 & 0.13 & 11.7 & 2.19 & 19 & 14.7 & 0.1 & 0.5 \\
\hline YS32 & 6.35 & 0.08 & 0.55 & 0.18 & 0.89 & 0.14 & 2.42 & 1.01 & 4.6 & - & - & - \\
\hline YS34B & 6.12 & 0.11 & 0.51 & 0.16 & 0.96 & 0.08 & 8.07 & 4.86 & 51 & 28.4 & 0.2 & 0.6 \\
\hline YS39 & 2.77 & 0.19 & 0.57 & 0.15 & 1.49 & - & 0.34 & 2.07 & 8.2 & 3.2 & 0.2 & 0.6 \\
\hline
\end{tabular}

a Plant wax lipids: Sum of HMW $n$-alkanoic acids $\left(\Sigma C_{20}-C_{30}\right)$ and $n$-alkanes $\left(\Sigma C_{20}-C_{32}\right)$, ratio of HMW/LMW $n$-alkanes (LMW, $\left.\Sigma C_{17}-C_{19}\right)$. CuO oxidation reaction products: Lignin ( $\left(\right.$ lignin phenols, $\left.\Lambda_{8}\right)$, cinnamyl phenols over vanillyl phenols $(C / V)$, syringyl phenols over vanillyl phenols $(S / V)$, $p$-hydroxyacetophenone over p-hydroxybenzoic acids ( $\mathrm{Pn} / \mathrm{P})$, and p-hydroxybenzoic acids over vanillyl phenols (P/V).

A pattern like this could be explained not only by dilution of the riverine water into the marine but also by removal of lignin from the $\mathrm{COC}$ pool. The differences in actual river inputs to the marine environment are not resolvable by salinity differences alone. We draw most of our conclusions based on ratio proxies which are far less sensitive to dilution than actual concentrations. The lowest lignin concentrations were found at stations YS39 and YS4 (Figure 2a), which both are samples farthest offshore (Figure 1). This is in agreement with a recent report on another class of terrestrial biomarkers, the branched Glycerol Dialkyl Glycerol Tetraethers, in the underlying sediment, decreasing away from the shore, indicating a reduced influence of riverine organic matter [Doğrul Selver et al., 2015]. These patterns probably mirror the larger share of woody plants and different vegetation pattern in the Lena catchment compared to farther east. The Lena River also reaches farther south than the Indigirka and Kolyma drainage areas. Addressing whether the declining lignin content is a result of degradation is assessed in sections below.

The highest lignin phenol content $(25 \mathrm{mg} / \mathrm{g} \mathrm{OC}$ ) was observed in samples outside the Yenisey; its catchment is influenced by a relatively warmer climate and more woody vegetation than the others. The Ob catchment has a comparable climate and vegetation, but showed a somewhat lower COC lignin content (13 mg/g OC). Ob has a catchment with especially abundant mosses and an extensive bog system [Opsahl et al., 1999; Breckle and Walter, 2002; Feng et al., 2013], which is consistent with the observed lower fraction lignin phenols or woody plant matter.

Lignin phenols and individual $\mathrm{CuO}$ oxidation reaction products also carry structurally embedded information on which type of plants and tissues they have been derived from [Goni and Hedges, 1990]. Cutin acids, derivatives from plant wax cuticles [Kolattukudy and Walton, 1972], were not detectable in the COC pool (data in supporting information). In the corresponding SOC [Tesi et al., 2014] the average cutin acid concentration was $1.4 \mathrm{mg} / \mathrm{g}$ OC. Tesi et al. [2014] also report cutin acids in ICD-OC/Yedoma. The lack of cutin residues could perhaps be an operational effect, i.e., cutin acids could be too small to end up in the cross-flow ultrafiltered COC fraction, or they could be associated to a different matrix.

Both cutin acids and cinnamyl phenols are ubiquitous in nonwoody vascular plant tissues. Syringyl phenols, however, are derived only from angiosperms. The ratio of syringyl to vanillyl phenols (S/V) has been reported to not undergo any particular change despite extensive bulk degradation [Opsahl and Benner, 1995] and is a common source proxy to separate angiosperm versus gymnosperm tissues. These source tracers have been applied in earlier studies of the Arctic region. For DOC and POC, the S/V has also been expressed by Lobbes et al. [2000] as percentage of tundra (versus taiga) contributed material. These source ratios are far less sensitive to dilution of freshwater into a marine system but could be altered as a result of mixing into an already existing pool of a different composition. The $\mathrm{S} / \mathrm{V}$ ratio for all $\mathrm{COC}$ in the current study ranged from 0.3 to 0.7 (Figure $2 \mathrm{~b}$ and Table 2), which would reflect a tundra fraction of around a fifth up to full tundra coverage according to the classification suggested by Lobbes et al. [2000]. As a comparison, Sphagnum 
leachate was reported in Spencer et al. [2008] at an S/V of 0.95, and boreal gymnosperm tissue at an S/V of 0.1. The high S/V ratios of the COC suggest a high angiosperm abundance of the catchment. The S/V values are higher in the easternmost samples outside Indigirka and Kolyma Rivers (Figure 2b and Table 2), both in COC (this study) and in SOC values [Tesi et al., 2014]. This likely reflects the vegetation differences with more northerly confined catchments mostly void of boreal vegetation to the east. The observations are also in line with the suggestion by Lobbes et al. [2000] that both higher altitudes and latitudes can give amplified S/V ratios, signaling a relatively larger contribution of angiosperm organic matter for these eastern samples.

The cinnamyl to vanillyl phenols ratio (C/V) is commonly used as a proxy for nonwoody organic matter sources [Hedges and Mann, 1979; Spencer et al., 2008]. The C/V ratio tends to change slightly through decomposition [Opsahl and Benner, 1995]. The presence of cinnamyl tissue still indicates an herbaceous source but may not be a reliable quantitative proxy. The cinnamyl over vanillyl C/V ratio was low throughout the whole COC data set (Table 2) and may suggest dominant woody plant matter source contribution to COC. Values were between 0.01 and 0.24 . In the more southern reaching catchments, a low C/N ratio reflects a larger proportion of woody material, but no specific trends were seen over the data set. The C/V ratio in the Ob sample was higher than the $\mathrm{C} / \mathrm{V}$ ratio in Yenisey and may reflect herbaceous plant matter sources in the extensive West Siberian wetland in the Ob catchment.

There were clear continental trends in both p-hydroxyphenone/p-hydroxybenzene (Pn/P) and p-hydroxybenzene/vanillyl phenol (P/V) ratios (Figures $2 \mathrm{c}$ and $2 \mathrm{c}$ and Table 2). $\mathrm{Pn}$ is highly abundant in peat and Sphagnum [Williams et al., 1998] but found to be low in relation to $\mathrm{P}$ both in vascular plants and boreal lakes and soils (Pn/P 0.14-0.22 [Hedges et al., 1986; Williams et al., 1998; Houel et al., 2006]). Furthermore, it is worth mentioning that marine $\mathrm{OC}$ also yields $\mathrm{P}$ products upon $\mathrm{CuO}$ oxidation, likely from aromatic amino acids such as tyrosine and phenylalanine [Goni and Hedges, 1995]. Pn/P in COC ranges from 0.15 to $0.30(0.15-0.22$ if exclude the one YS-2 sample; Figure $2 c$ and Table 2 ) and shows a trend over the ESAS with lower values toward the east $\left(p<0.001, r^{2}=0.83\right.$ in linear regression, apart from YS2, YS3, and the most offshore sample YS4). The opposite trend is seen for $\mathrm{P} / \mathrm{V}$ of the same area (Figure $2 \mathrm{~d}$, Table $2 ; p<0.01, r^{2}=0.84$ in linear regression, apart from YS2, YS3, and the most offshore sample YS4). These contrasting trends indicate that the P contribution to ESAS was derived primarily from marine sources rather than Sphagnum mosses, while the $P$ in the west (Kara Sea receptor) had large influence from Sphagnum. The current study reveals lower $\mathrm{Pn} / \mathrm{P}$ ratios in COC (0.15-0.22) than reported for Arctic river DOC, which were consistently higher than 0.22 (in Lena, Indigirka, and Kolyma 0.30-0.39) measured both at spring flush, midflow, and base flow [Amon et al., 2012]. The $\mathrm{Pn} / \mathrm{P}$ signal from COC in the Kara Sea sample outside Ob was the highest measured $\mathrm{Pn} / \mathrm{P}(0.30)$ but was still somewhat lower than the reported Ob river $\mathrm{DOC} \mathrm{Pn} / \mathrm{P}$ of 0.37 [Amon et al., 2012]. The low $\mathrm{Pn} / \mathrm{P}$ ratio in combination with the eastward contrasting trend of the $\mathrm{Pn} / \mathrm{P}$ to the $\mathrm{P} / \mathrm{V}$ ratios suggests a moderate contribution of Sphagnum to $\mathrm{COC}$ in the western region near the stations outside $\mathrm{Ob}$ and Yenisey, and an even lower Sphagnum contribution eastward with instead an increasing marine contribution of $P$.

Plant wax-derived high molecular weight (HMW) n-alkanes [Eglinton and Hamilton, 1967] are well-used markers for tracing terrestrial matter in the marine environment [Simoneit, 1977; Schubert and Stein, 1996; Yunker et al., 2005, 2011]. Plant wax lipids have been used earlier to characterize SOC and POC from samples of the same ESAS regimes as for the COC in this study [van Dongen et al., 2008a; Vonk et al., 2010a, 2010b; Karlsson et al., 2011]. However, while POC and SOC concentrations of HMW n-alkanes $\left(C_{20}-C_{34}\right)$ were between 0.05 and $2.1 \mathrm{mg} / \mathrm{g}$ OC (Table 2), concentrations in COC were below detection limits. The lack of plant wax lipids in the colloidal pool is in parallel to the equally undetectable cutin acids, which are structurally similar to the acyl lipids. This absence could be due to an operational effect, where the free $n$-alkanes and $n$-alkanoic acids nor cutin acids remain in this colloidal size fraction. Another explanation may be that the terrestrial lipid components have already been degraded in this pool. Photooxidation is known to efficiently degrade lignin in DOC [Hernes and Benner, 2003; Spencer et al., 2008]. For example, Opsahl and Benner [1998] show extensive removal of lignin with photooxidation over the same timescale as the Lena river course.

Taken together, the lignin phenol fingerprint demonstrates a clear geospatial trend in the relative contribution of different terrestrial sources to coastal $O C$ in going from the west to the east, consistent with changing extent of permafrost coverage and vegetation cover. This is likely due to either dilution, a mixing with preexisting material or a degradation effect, discussed in coming sections. The wax lipids and cutins were not 

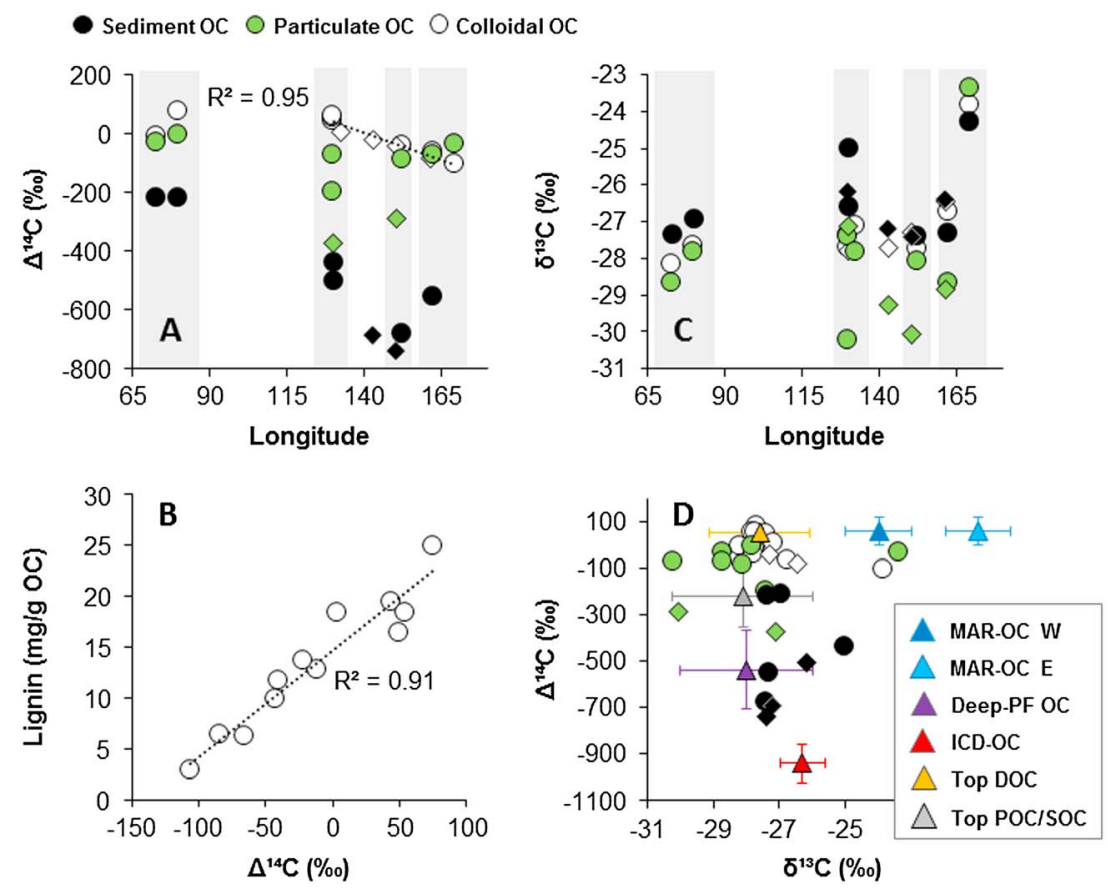

Figure 3. Comparison of longitudinal spread of dual-carbon isotopes and end-member signals of different carbon source pools over the Eurasian Arctic margin. Surface water colloidal organic carbon (COC, white circles), particulate organic carbon (POC, green circles), and surface sediment organic carbon (SOC, black circles) from July to August 2008. (a) Radiocarbon signal $\Delta^{14} \mathrm{C}(\%)$ over longitude. (b) Radiocarbon. (c) Stable carbon signal $\delta^{13} \mathrm{C}(\%)$ over longitude (d) Radiocarbon over stable carbon isotope signals and end-member values derived from literature data on different carbon pools. Detailed description of end-members can be found in section 3.5. Shaded bars indicate area of major river outflows, from left to right: Ob plus Yenisey, Lena, Indigirka, and Kolyma. Erosion hot spot stations are denoted as diamonds.

detected in the COC, in contrast to in the POC and SOC compartment, suggesting that different terrestrial carbon pools partition into different aquatic carrier phases.

\subsubsection{Radiocarbon Signals}

The radiocarbon signals and thus ages of the $\mathrm{COC}$ in the collection of samples were generally much younger than in the POC and SOC. The $\mathrm{COC}^{14} \mathrm{C}$ signals ranged from 75 to -106 , corresponding to ages from modern to $845{ }^{14} \mathrm{C}$ years (Table 1 and Figure 3a). This is in line with one of the first age estimates of HMW DOC (COC) in Arctic Rivers by Benner et al. [2004] that identified dissolved organic matter (DOM) in surface waters exported by Eurasian Arctic Rivers as modern and highly terrestrial. This is also consistent with several other Arctic River studies wherein DOC (often CFF collected as HMW DOC or COC) was found at ages of a few hundred years before present [Guo and Macdonald, 2006; Neff et al., 2006; Guo et al., 2007; Raymond et al., 2007].

The ${ }^{14} \mathrm{C}-\mathrm{COC}$ from along the Eurasian Arctic shelf seas was much lower than values reported for $\mathrm{SOC}$ (analysis of variance (ANOVA) $p<0.001$ ) but similar to those of POC; n.b.- samples from the three compartments were collected at the same stations. The ${ }^{14} \mathrm{C}-\mathrm{COC}$ material in the easternmost samples off Indigirka and Kolyma Rivers was overlapping in signal with ${ }^{14} \mathrm{C}-\mathrm{POC}$ (this study and Vonk et al. [2010a, 2010b]) (Figure 3a), though the ${ }^{14} \mathrm{C}-\mathrm{POC}$ data set exhibited a larger variation. However, apart from the two most depleted POC data points at station YS14 [from Sanchéz-García et al., 2011] and station YS26, both situated right outside erosion hots pots, the POC is overall comparable in signal and thus age to the COC (ANOVA, $p=0.08$ ).

There was also an alongshore/longitudinal trend across the ESAS in the COC radiocarbon signal, with more depleted material in the east where salinity increases (Figure 3a, linear regression, $r^{2}=0.95, p<0.001$; Figure S2 linear regression $r^{2}=0.72, p<0.01$ ). This same continent-scale trend has also been reported for the ${ }^{14} \mathrm{C}$ signal of SOC outside the mouths of the largest Eurasian Arctic Rivers [Guo et al., 2004; Gustafsson et al., 2011]. The three most ${ }^{14} \mathrm{C}$-depleted stations in this set of sediment samples are from the YS23, YS26, and YS30, out of which YS23 and YS26 are coastal erosion hots pots and YS30 from outside the Indigirka River 
(Figure 1), all at a $\Delta^{14} \mathrm{C}$ around $-700 \%$. The sample outside the Kolyma (YS39) in this study, however, was somewhat younger but still had a $\Delta^{14} \mathrm{C}$ of $-550 \%$ o [Vonk et al., 2010a, 2010b]. This slight change toward the east could also be seen for the POC (Table 1) and may be an effect of increasing younger material from Pacific-influenced waters toward the east.

The radiocarbon signal of $\mathrm{COC}$ was more enriched at the $\mathrm{Ob}$ and Yenisey locations than the eastern counterparts. This difference was more prominent in SOC, where ${ }^{14} \mathrm{C}$ values were at least $200 \%$ more enriched than in the sediments from Laptev Sea/East Siberian Sea (ESS) (our data [Gustafsson et al., 2011; Vonk et al., 2012]). This is likely due to an echo of peat deposits of the $\mathrm{Ob}$ and Yenisey catchments, releasing younger material than the Pleistocene ICD material of the Kolyma, Indigirka, and northern/lower Lena areas.

The OC-normalized lignin content of the COC pool was strongly correlated to radiocarbon, with a more enriched (i.e., modern) radiocarbon signature at higher concentrations of OC-normalized lignin phenols (Figure $3 \mathrm{~b}$, linear regression $r^{2}=0.91, p<0.001$ ). As the bulk sample gets more radiocarbon depleted the amount of (OC-normalized) lignin decreases. Since lignin has been found and dated old in Yedoma/ICDOC [Tesi et al., 2014], the young lignin of COC must be derived from a different terrestrial source, such as contemporary topsoil OC. Feng et al. [2013] report compound-specific radiocarbon dating of lignin in sediments off major river mouths along this same Eurasian Arctic coast, and Schreiner et al. [2014] date bulk POC outside the permafrost-draining Colville River. They both hypothesize lignin to be derived from a younger surface layer source.

The COC in this data set was overall mostly modern but slightly more depleted in the east (Figure 3a), with a lignin component from surface soil/topsoil OC that was highly correlated to the radiocarbon bulk signature (Figure 3b).

\subsubsection{Stable Carbon Signatures}

The $\delta^{13} \mathrm{C}-\mathrm{COC}$ signal indicated overall mixed source contributions but a clear effect of marine-influenced waters in the eastern reaches of the study region. The $\delta^{13} \mathrm{C}-\mathrm{COC}$ values varied between -28.2 and -23.9 (average at -27.1; Table 1 and Figure 3c). These $\delta^{13} \mathrm{C}-\mathrm{COC}$ values compared well with magnitude and patterns from earlier studies of Arctic DOC [Lara et al., 1998; Neff et al., 2006] and POC [Rachold and Hubberten, 1999; McClelland et al., 2008; Sanchéz-García et al., 2011]. There is no large difference between the $\delta^{13} \mathrm{C}$ values of POC, SOC, and COC, but the range is the largest for POC (our data [Sanchéz-García et al., 2011]). In general, the POC seems more depleted than corresponding $\mathrm{COC}$, which in turn is often more depleted than the corresponding SOC [Vonk et al., 2010a, 2010b; Karlsson et al., 2011] (Figure 4c). The most depleted $\delta^{13} \mathrm{C}$ values are seen in the POC pool reported from the SE Laptev and ESS at -30\%o [Sanchéz-García et al., 2011]. The shallow parts of the Eurasian Arctic Ocean shelf normally experiences wind-driven turbidity, benthic transport, and winnowing of OM on the sea floor [Are et al., 2002]. These are processes that can also contribute to a varying $\delta^{13} \mathrm{POC}$ signature [Coppola et al., 2007]. However, the year of sampling (2008) was a year of unusually high Lena River discharge and low wind conditions, resulting in lower turbidity and an accumulation-sedimentation regime of the Laptev Sea that normally occurs only during ice cover [Charkin et al., 2011].

The Pacific influence in the eastern ESAS study region was seen in the stable carbon isotope signature of COC. Highly enriched values of $\delta^{13} \mathrm{C}-\mathrm{COC}$ reflect a different source of carbon at station YS39 off the Kolyma River for all three carbon fractions (our data [Sanchéz-García et al., 2011; Vonk et al., 2010a, 2010b]; Table 1 and Figures $3 c$ and S2, linear regression with salinity, $r^{2}=0.45, p<0.001$ ). The phytoplankton in the Pacific water masses utilize a different carbon source and hold a different stable carbon signature than the ones in the Laptev Sea/ESS [e.g., Alling et al., 2010; Andersson et al., 2009; Pipko et al., 2008]. Highly depleted $\delta^{13} \mathrm{C}$ values of phytoplankton on the western ESAS (Laptev Sea) have been suggested to originate from DIC of degraded terrestrial matter that initially carry a more depleted signature [Andersson et al., 2009; Alling et al., 2012]. Marine plankton tends to have more depleted $\delta^{13} \mathrm{C}$ values in higher latitudes [Degens, 1969; Fontugne and Duplessy, 1978].

Taken together, the stable carbon isotopes in COC indicate mixed source contributions. The relative influence of each source can be quantitatively assessed by merging together stable carbon isotopes and radiocarbon measurements (i.e., dual-carbon isotope mixing model) as discussed in the next section.

\subsubsection{End-Member Mixing Model Analysis}

The sources that contributed carbon to these samples have different carbon isotope signatures, here divided into three main sources represented by in total six region/source-compartment-specific values (Figures $3 d$ and $3 e$ and Table 3 ) as discussed in detail in section 3. To assess the relative contribution of the different 

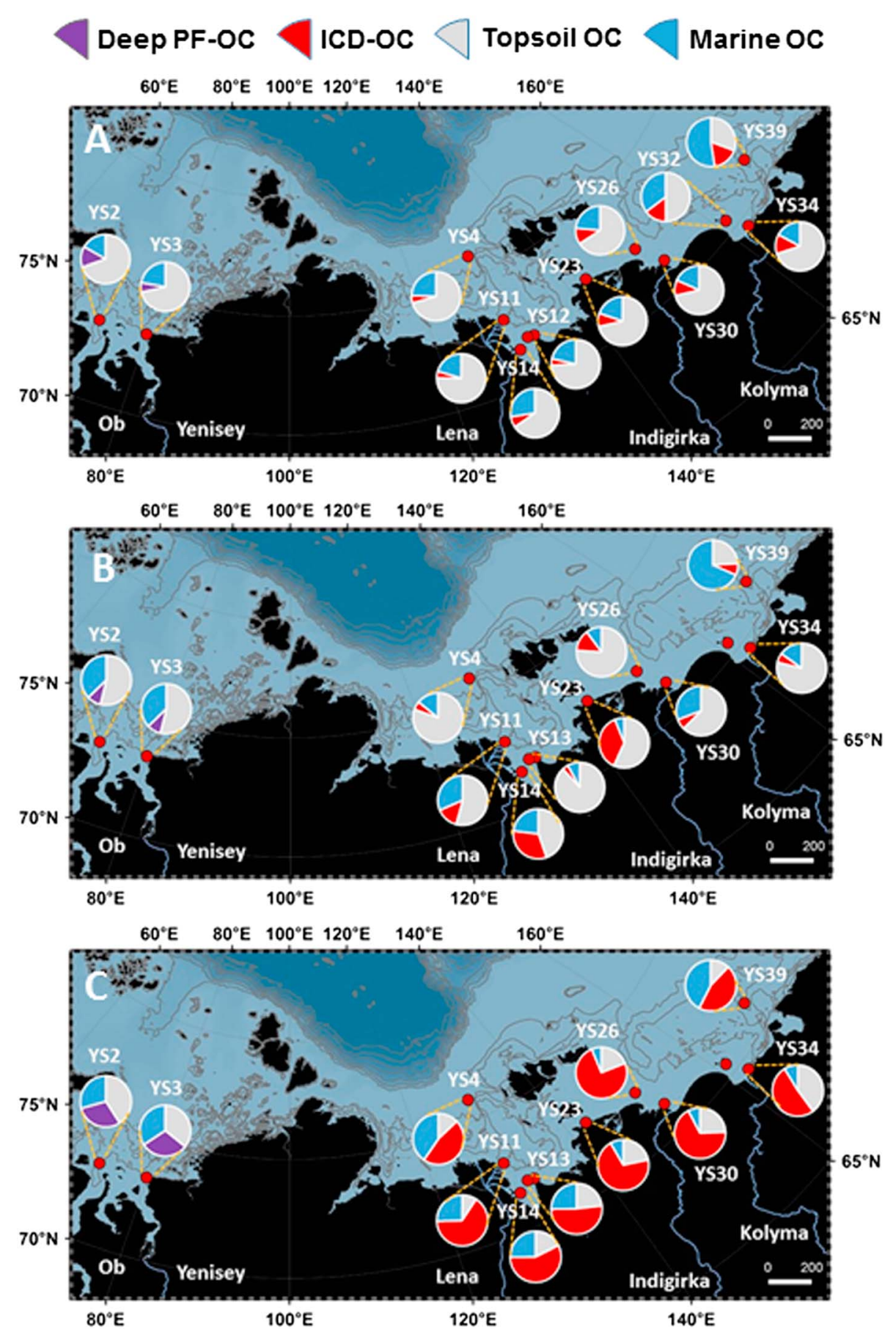

Figure 4. Areal distribution of dual-carbon isotope source apportionment. Surface plots of Eurasian Arctic margin with inserted pie charts of source contributions as derived in dual-carbon end-member mixing model Monte Carlo simulation. The three sources represented are (i) marine plankton OC (blue segment), (ii) topsoil OC (light grey segment), and (iii) ice complex deposit/Yedoma/mineral soil OC over Laptev and East Siberian Seas (ICD-OC; red segment) or deep permafrost (Deep PF-OC; purple segment) in the Kara Sea. A thorough discussion and source description of employed end-members are given in section 3.5. The investigated carbon pools are (a) surface water colloidal organic carbon (COC), (b) surface water particulate organic carbon (POC), and (c) surface sediment organic carbon (SOC) from July to August 2008. 
Table 3. Results From Three-Source Mixing Model ${ }^{a}$

\begin{tabular}{|c|c|c|c|}
\hline Kara Sea & Topsoil OC & Deep PF-OC & Marine OC \\
\hline $\operatorname{COC}$ & 0.69 & 0.10 & 0.19 \\
\hline POC & 0.57 & 0.09 & 0.31 \\
\hline SOC & 0.38 & 0.29 & 0.31 \\
\hline ESAS & Topsoil OC & ICD-OC & Marine OC \\
\hline $\mathrm{COC}$ & 0.64 & 0.09 & 0.26 \\
\hline POC & 0.62 & 0.14 & 0.23 \\
\hline SOC & 0.20 & 0.58 & 0.21 \\
\hline All data & Topsoil OC & ICD-OC or deep PF-OC & Marine OC \\
\hline $\mathrm{COC}$ & 0.65 & 0.09 & 0.25 \\
\hline POC & 0.61 & 0.13 & 0.24 \\
\hline SOC & 0.23 & 0.53 & 0.23 \\
\hline End-member & $\delta^{13} \mathrm{C}$ & $\Delta^{14} C$ & \\
\hline Marine $\mathrm{OC}$ east of $165^{\circ} \mathrm{E}$ & $\delta^{13} \mathrm{C}-21.0 \pm 1 \%$ & $\Delta^{14} \mathrm{C} 60 \pm 60 \%$ & \\
\hline Marine OC west of $165^{\circ}$ & $\delta^{13} \mathrm{C}-24.0 \pm 1 \%$ & $\Delta^{14} \mathrm{C} 60 \pm 60 \%$ & \\
\hline ICD-OC & $\delta^{13} C-26.3 \pm 0.67 \%$ o & $\Delta^{14} \mathrm{C}-940 \pm 84 \% 0$ & \\
\hline Deep PF-OC & $\delta^{13} \mathrm{C}-28.0 \pm 2 \%$ & $\Delta^{14} \mathrm{C}-536 \pm 171.5 \%$ & \\
\hline Topsoil POC/SOC & $\delta^{13} \mathrm{C}-28.0 \pm 2 \%$ & $\Delta^{14} \mathrm{C}-219 \pm 134.5 \%$ & \\
\hline Topsoil DOC/COC & $\delta^{13} \mathrm{C}-27.6 \pm 1.5 \%$ & $\Delta^{14} \mathrm{C} 53.9 \pm 43.1 \%$ & \\
\hline
\end{tabular}

${ }^{a}$ Fractional contributions to surface water colloidal organic carbon (COC), surface water particulate organic carbon (POC) and surface sediment (SOC) from marine plankton OC (marine), active layer and surface topsoil OC (topsoil), and deep/old yedoma/mineral soil OC (ICD) or deep permafrost OC (deep PF-OC), as derived by Monte Carlo simulation of a dual-carbon three-end-member mixing analysis (EMMA). The employed end-member values are listed at end and clarified with references and details in the main text (section 3 ). Results are given as median values and divided in three sections: (i) the ESAS stations, (ii) only the Kara Sea stations (YS2 and YS3), and (iii) the combined data (all data). Station specific fractions and their $95 \%$ confidence interval values are given in the supporting information.

sources to each sample, an end-member mixing model analysis (EMMA) was run as a Monte Carlo simulation of the observed dual-isotope values in concert with the three relevant source end-members for a given region/compartment (Table 3).

The modeled contribution from terrestrial topsoil OC dominates the COC pool, estimated to 65\% (30-90\%), and was on average over twice the size of the marine OC, estimated to 25\% (3-58\%; Figure 4 and Table 3). This is consistent with the high lignin concentration and the buoyant nature of colloidal matter and the resulting very small contributions of mineral-associated ICD-OC at 9\% (1-23\%; Figure 5). This COC composition was similar for the $\mathrm{Ob}$ and Yenisey samples (Figure 4 and Table 3), with a dominant topsoil component of $69 \%(30-93 \%)$, a marine fraction of 19\% (1-53\%), and a small contribution from deeper permafrost deposits at 10\% (1-33\%). In contrast, sediments reported in Karlsson et al. [2011] and Vonk et al. [2010a, 2010b, 2012, 2014] had high modeled fractions of ICD-OC.

The highest fractions of ICD-OC in COC were either close to the Kolyma River mouth YS32 (15\%) or at an offshore station, YS39 (17\%). This appears to (i) mirror the large share of Yedoma/ICD deposits in the Kolyma catchment (Figure 1) and (ii) show an increase of the ICD-OC fraction offshore compared to nearshore-or rather a decrease of the topsoil component offshore. This COC pattern corroborates the suggestion that the topsoil $\mathrm{OC}$ is derived from a surface soil component (including lignin) which is labile and preferentially degraded and/or settled with time and/or transport [e.g., Vonk et al., 2010a, 2010b; Tesi et al., 2014].

The slightly higher percentages of ICD-OC and the somewhat older age of COC toward the east can be seen as a reflection of the watershed characteristics. The eastern areas are where erosion-prone coast is more common, as well as where there is a larger extent of ICD [Lantuit et al., 2012, 2013; Günther et al., 2013]. There is also a gradually decreasing influence of the Lena river plume (diluted and/or degrading) toward the east of the ESAS. Though the coastal current along ESAS is generally directed eastward from Laptev Sea through the Dmitry Laptev Strait [Steele and Ermold, 2004], the Lena runoff-driven eastward current was less distinct than usual in 2008. The older ages and higher fraction ICD were also seen in the SOC sample set (reported on earlier in Vonk et al. [2010a], Karlsson et al. [2011], and Tesi et al. [2014]). 
Sediment $O C \bigcirc$ Particulate $O C \bigcirc$ Colloidal OC

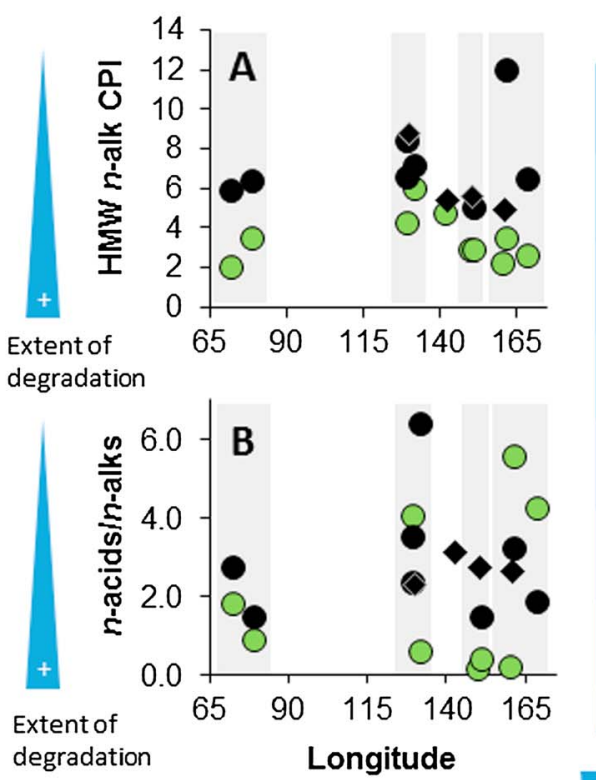

degradation

\section{Longitude}

Figure 5. Molecular proxies of relative degradation state for terrestrial organic matter from the Eurasian Arctic margin in surface water colloidal organic carbon (COC, open circles), surface water particulate organic carbon (POC, green filled circles), and surface sediment organic carbon (SOC, black circles) from July to August 2008. (a and b) Solvent-extractable terrestrial lipid markers, with lower values corresponding to more degraded states. High molecular weight (HMW) $n$-alkane carbon preference index (CPl; $\mathrm{CPI}$ of $n$-alkanes $=\frac{1}{2}\left(\frac{C_{25}+C_{27}+C_{29}+C_{31}+C_{33}}{C_{24}+C_{26}+C_{28}+C_{30}+C_{32}}+\frac{C_{25}+C_{27}+C_{22}+C_{31}+C_{33}}{C_{26}+C_{28}+C_{30}+C_{32}+C_{34}}\right)$ ) (Figure 5a). Ratio HMW $n$-alkanoic acids $\left(\Sigma \mathrm{C}_{20}-\mathrm{C}_{32}\right)$ to HMW $n$-alkanes $\left(\Sigma \mathrm{C}_{20}-\mathrm{C}_{34}\right)$ (Figure $\left.5 \mathrm{~b}\right)$. (c-e) CuO oxidation reaction product-based proxies. Syringic acid over syringaldehyde (Figure $5 \mathrm{c}$ ), vanillic acid over vanillin (Figure 5d), and 3,5-dihydroxybenzoic acid/vanillyl phenols (Figure 5e). Extent of degradation shown in Figures $5 \mathrm{a}, 5 \mathrm{~b}$, and $5 \mathrm{e}$, by proxy on blue scale bar, is more degraded on thicker end. Shaded bars indicate area of major river outflows, from left to right: Ob plus Yenisey, Lena, Indigirka, and Kolyma. Erosion hot spot stations are denoted as diamonds.

The stable carbon compositions of COC, POC, and SOC at station YS39 echoed the marine influence from the Pacific (Figures $3 \mathrm{C}$ and 4). The marine fraction was highest in the POC pool. This likely suggests not only that (i) marine phytoplankton largely existed in a particulate form but also that (ii) the marine pool was labile and a large part of it was removed in the water column before reaching the sea floor. This distribution is widely seen in continental margins across the world, where a large share of the water column marine OC is not reaching the seafloor and TerrOM has larger preservation potential into the SOC. This is also in line with earlier findings in the Eurasian Arctic where bulk POC removal from the water column was seen over the ESAS [SanchézGarcía et al., 2011; Kraberg et al., 2013]. Marine OC has, moreover, been shown to be a larger fraction in sinking POC compared to surface POC and SOC (where the fraction marine from similar source modeling was 21-35\% and 7-9\%, respectively, [Vonk et al., 2014]). This was equally suggested to mirror settling properties of marine phytoplankton and/or a higher degradability of marine OC than both topsoil OC and ICD-OC.

Buoyant surface water COC is more readily advected horizontally than both POC and SOC. Hence, there would be a natural decoupling between these pools. SOC is a slower more integrated signal combining several seasonal cycles thus reflecting the pool that survives a preceding transit/residence time, while the COC is reflecting a more instantaneous picture and water movements. The marine fraction in the $\mathrm{COC}$ pool was less 
Table 4. Degradation Proxies of Surface Water Colloidal, Surface Water Particulate, and Surface Sediment Organic Matter Samples From the East Siberian Arctic Shelf ${ }^{a}$

\begin{tabular}{|c|c|c|c|c|c|c|c|c|c|c|}
\hline \multicolumn{4}{|c|}{ Colloidal OC } & \multicolumn{2}{|c|}{ Particulate OC } & \multicolumn{5}{|c|}{ Sediment OC } \\
\hline Station & $\mathrm{Sd} / \mathrm{SI}$ & $\mathrm{Vd} / \mathrm{VI}$ & $3,5 \mathrm{Bd} / \mathrm{V}$ & HMW Acids/HWM Alks & Alk CPI 24-34 & HMW Acids/HWM Alks & Alk CPI 24-34 & $\mathrm{Sd} / \mathrm{SI}$ & $\mathrm{Vd} / \mathrm{Vl}$ & $3,5 \mathrm{Bd} / \mathrm{V}$ \\
\hline YS2 & 0.80 & 0.98 & 0.57 & 1.75 & 1.95 & 2.68 & 5.82 & - & - & - \\
\hline YS3 & 0.92 & 0.82 & 0.53 & 0.83 & 3.33 & 1.42 & 6.28 & - & - & - \\
\hline YS4 & 1.62 & 1.34 & 0.40 & - & - & 3.44 & 6.46 & 0.82 & 1.21 & 0.38 \\
\hline YS11 & 0.99 & 0.80 & 0.71 & 4.00 & 4.09 & 2.26 & 8.31 & - & - & - \\
\hline YS12 & 1.21 & 1.07 & 0.47 & 0.51 & 5.84 & 6.31 & 7.07 & - & - & - \\
\hline YS14 & 1.21 & 0.95 & 0.55 & - & - & 2.28 & 8.75 & 0.48 & 0.59 & 0.14 \\
\hline YS23 & 1.02 & 0.91 & 0.54 & - & 4.63 & 3.12 & 5.39 & 0.37 & 0.48 & 0.16 \\
\hline YS26 & 1.15 & 1.00 & 0.62 & 0.09 & 2.77 & 2.70 & 5.57 & 0.28 & 0.46 & 0.29 \\
\hline YS30 & 1.07 & 0.90 & 0.54 & 0.30 & 2.81 & 1.38 & 4.88 & 0.38 & 0.45 & 0.19 \\
\hline YS32 & 1.23 & 1.04 & 0.81 & 0.10 & 2.09 & 2.61 & 4.93 & - & - & - \\
\hline YS34B & 1.35 & 1.02 & 0.87 & 5.50 & 2.29 & 3.16 & 9.23 & 0.56 & 0.68 & 0.17 \\
\hline YS39 & 1.16 & 1.06 & 0.96 & 4.17 & 2.15 & 1.77 & 4.88 & 0.73 & 1.16 & 0.64 \\
\hline
\end{tabular}

a Plant wax lipids: $\mathrm{HMW} n$-alkane carbon preference index (CPI; CPI of $n-$ alkanes $=\frac{1}{2}\left(\frac{C_{25}+C_{27}+C_{29}+C_{33}+C_{33}}{C_{24}+C_{26}+C_{28}+C_{30}+C_{25}+C_{27}+C_{29}+C_{31}+C_{33}} C_{26}+C_{28}+C_{30}+C_{32}+C_{34}\right)$. Ratio of high molecular weight (HMW) $n$-alkanoic acids $\left(\sum C_{20}-C_{30}\right)$ to HMW $n$-alkanes $\left(\sum C_{20}-C_{32}\right)$. CuO oxidation reaction product-based proxies: vanillic acid over vanillin, syringic acid over syringaldehyde, and 3,5-dihydroxybenzoic acid/vanillyl phenols.

varied in distribution (16-52\%) than in POC (6-68\%), while the topsoil component was in the same range for both pools (31-90\% versus 32-88\%) all in Figure 4 and Table 3. SOC held a smaller topsoil OC contribution than both POC and COC, especially over the ESAS. This could reflect that topsoil OC is more readily degraded than ICD-OC [Vonk et al., 2010a, 2010b, 2015; Karlsson et al., 2011]. However, it cannot be excluded that a larger offshore sedimentary share of ICD-OC could also indicate an additional source such as subsea permafrost input or near-bottom-driven input of terrestrial OC [Vonk et al., 2010a, 2012]. Winnowing of surface sediment and strong nepheloid layer transport has been shown over the ESAS sea floors due to the shallow depths and turbid waters [Dudarev et al., 2006; Charkin et al., 2011; Are et al., 2002]. Such a near-bottom transport mechanism could potentially disperse a mineral-ballasted fraction such as ICD-OC over the sea floor, without being echoed in the overlying particulate or suspended OC pools.

Taken together, the source apportionment showed a stark contrast in composition and behavior of the COC pool compared to the corresponding POC and SOC. The COC was clearly dominated by topsoil OC, with a very small contribution from ICD-OC. This suggests that the highly labile topsoil OC component dominates both the dissolved/colloidal and particulate forms. Pacific marine influence affects the composition of all $O C$ pools in the very east but suggests a potentially labile marine source with particulate properties that also reach the sediment. The results are consistent with a suggested mineral-ballasted ICD-OC component [Vonk et al., 2010a, 2012; Tesi et al., 2014; Karlsson et al., 2011; Are et al., 2002] settling out of the water column close to its source and possibly disperse through near-bottom transport far out on the shelf.

\subsection{Degradation-Diagnostic Molecular Composition of COC Versus POC and SOC}

Wax lipids and $\mathrm{CuO}$ oxidation reaction products indicate different relative degradation state of terrestrial OC in the colloidal, particulate, and sedimentary pools.

Plant wax-derived lipid markers were similarly applied to assess relative degradation state in the sampled OC pools but not determined in COC due to the absent free lipids in the colloidal pool. The $n$-alkane odd over even predominance, which is eroded during degradation [Brassel and Eglinton, 1983], is described by the carbon preference index (CPI) of HMW $n$-alkanes, where higher indices reflect less degraded material (Table 4). The $n$-alkane CPI was lower for POC than for SOC (ANOVA $p<0.001$; POC and SOC from our data and Vonk et al. [2010a]) and was 2.0-5.8 and 4.9-9.2 in POC and SOC, respectively (Table 4). Typical CPI values of the vascular plant epicuticular waxes vary between 4 and 10 [Tulloch, 1976; Rieley et al., 1991], but petroleum, kerogen, or pyrolytic products lack an odd over even predominance (CPI 1 [Farrington and Tripp, 1977]). The $n$-alkane CPI suggests the terrestrial component of POC to be more degraded than in SOC, which in turn is relatively undegraded. 
Another relative measure of degradation comes with the inherent chemical susceptibility of the carboxylic acid group on HMW $n$-alkanoic acids to degrade over the HMW $n$-alkanes [Brassel et al., 1984]. A similar pattern as for the HMW CPI was seen in the HMW $n$-alkanoic acid/n-alkane ratio $\left(\sum C_{20}-C_{30}\right.$ acids and $\sum C_{20}-C_{34}$ alkanes), as in the HMW CPI. The SOC values were 1.4-6.3, which is comparable to POC, but with a higher minimum value. POC HMW CPI values were 0.8-4.0 (our data [Vonk et al., 2010a]). Previously reported acid/alkane ratios for SOC over the ESAS vary between 0.14 and 11 [van Dongen et al., 2008a; Karlsson et al., 2011; Vonk et al., 2010a].

Lignin phenol markers that display high Ad/Al ratios of vanillyl and syringyl phenols are indicative of microbial and photochemical oxidation of propyl side chains of lignin which increases the carboxyl content of the remaining lignin [Opsahl and Benner, 1995, 1998]. These acid-to-aldehyde ratios (Ad/Al) are, therefore, commonly used to estimate relative degradation state of terrestrial organic matter in different marine environments [Hedges et al., 1988; Tesi et al., 2008; Goni et al., 2005]. Although the COC fraction shows values distinct from the SOC, some caution should be applied in the interpretation of these tracers because the inherent $\mathrm{Ad} / \mathrm{Al}$ ratio varies in different lignin sources. High levels have been suggested to originate from mineral sorption and/or vascular plant litter leachate. Intrinsic to this is that the leachate value would be higher in a dissolved fraction than in a particulate phase, e.g., it would affect the COC fraction more than the SOC.

The COC Sd/SI ratios were between 0.80 and 1.6, with an average of 1.1 (Table 4). The COC Vd/VI ratios were between 0.80 and 1.3 and averaged at 0.99 . The colloidal values are indeed higher than for the corresponding sediment values (average Vd/VI 0.7 and Sd/SI 0.5 [Tesi et al., 2014]). However, the COC values were lower than $\mathrm{Vd} / \mathrm{VI}$ and $\mathrm{Sd} / \mathrm{SI}$ values reported for Eurasian Arctic River DOC at 1.0-1.1 and 0.8, respectively, and also lower than values reported for Yukon and Mackenzie at around 0.8 (for both Vd/VI, Sd/SI [Amon et al., 2012]). Overall, the acid-to-aldehyde tracers are higher in the COC than in the SOC.

Another tracer commonly used for assessing degradation state of terrestrial matter is the 3,5-dihydroxybenzoic acid (3,5-Bd) to vanillyl phenols ratio [Prahl et al., 1994; Otto and Simpson, 2006; Goni et al., 2000]. The 3,5-Bd is an ubiquitous land-derived compound [Goni and Hedges, 1995] not produced in the marine environment [Dickens et al., 2007] and is highly resistant to degradation. In combination with the ubiquitous vanillyl phenols that are susceptible to degradation, the 3,5-Bd/N ratio is a tracer of fresh material and thus of relative degradation state. In COC, the 3,5-Bd/V ranged between 0.40 and 0.87 (average at 0.60 , Table 4 and Figure 5e), which compares well to ESAS river DOC values between 0.4 and 0.7 [Amon et al., 2012]. Tesi et al. [2014] show that the 3,5-Bd/N in SOC over the ESAS was lower than in the currently reported COC but increasing with distance from the coast. This suggests a moderate lignin degradation state of the $\mathrm{COC}$ pool in Arctic Eurasian shelf waters.

Overall, there is an agreement between the plant wax lipid and lignin biomarkers that the terrestrial component of the water column was degraded, and that $\mathrm{COC}$ was more degraded than the corresponding POC and SOC pools. This is consistent with the view that COC is largely degraded in the water column because of photochemical [Opsahl and Benner, 1998] or microbial reactivity [Opsahl and Benner, 1995] and only contributes a small fraction to the terrestrial $O C$ that is eventually accumulating in the underlying sediments.

\subsection{Relationships Between Age and Degradation Across the OC Continuum}

Several studies indicate a systematic pattern in the Eurasian Arctic margin of SOC being older yet less degraded with water column POC being younger, yet more degraded [Vonk et al., 2010a, 2010b, 2014; Karlsson et al., 2011]. This study is now extending this picture to the large COC (HMW DOC) pool, which is even younger and more degraded than the POC pool. HMW n-alkane CPI showed this pattern for POC and SOC (Figure 6a) and was largely shown also through the HMW $n$-alkanoic acid/n-alkane (Figure $6 \mathrm{~b}$ ). The same pattern with a more degraded terrestrial pool in COC than in SOC was similarly seen in the lignin degradation proxy 3,5-Bd/N (Figure 6e).

The COC pool is distinct from POC and SOC in its very low relative contribution of ICD-OC or deep PF-OC (for the Kara Sea recipient; Figure 4). The $\mathrm{COC}$ has a young ${ }^{14} \mathrm{C}$ age and is more degraded compared to the mineral-associated POC and SOC. POC with a higher fraction of old ICD-OC has been shown to correlate with water depth (higher fraction ICD closer to land [Karlsson et al., 2011; Vonk et al., 2010a, 2014]), which may be explained by a selective settling due to the mineral association acting as sinking weight. The ICD-OC from coastal erosion is believed to be deposited in the near-shore zones [Are, 1999; Dudarev et al., 2006; Wegner 


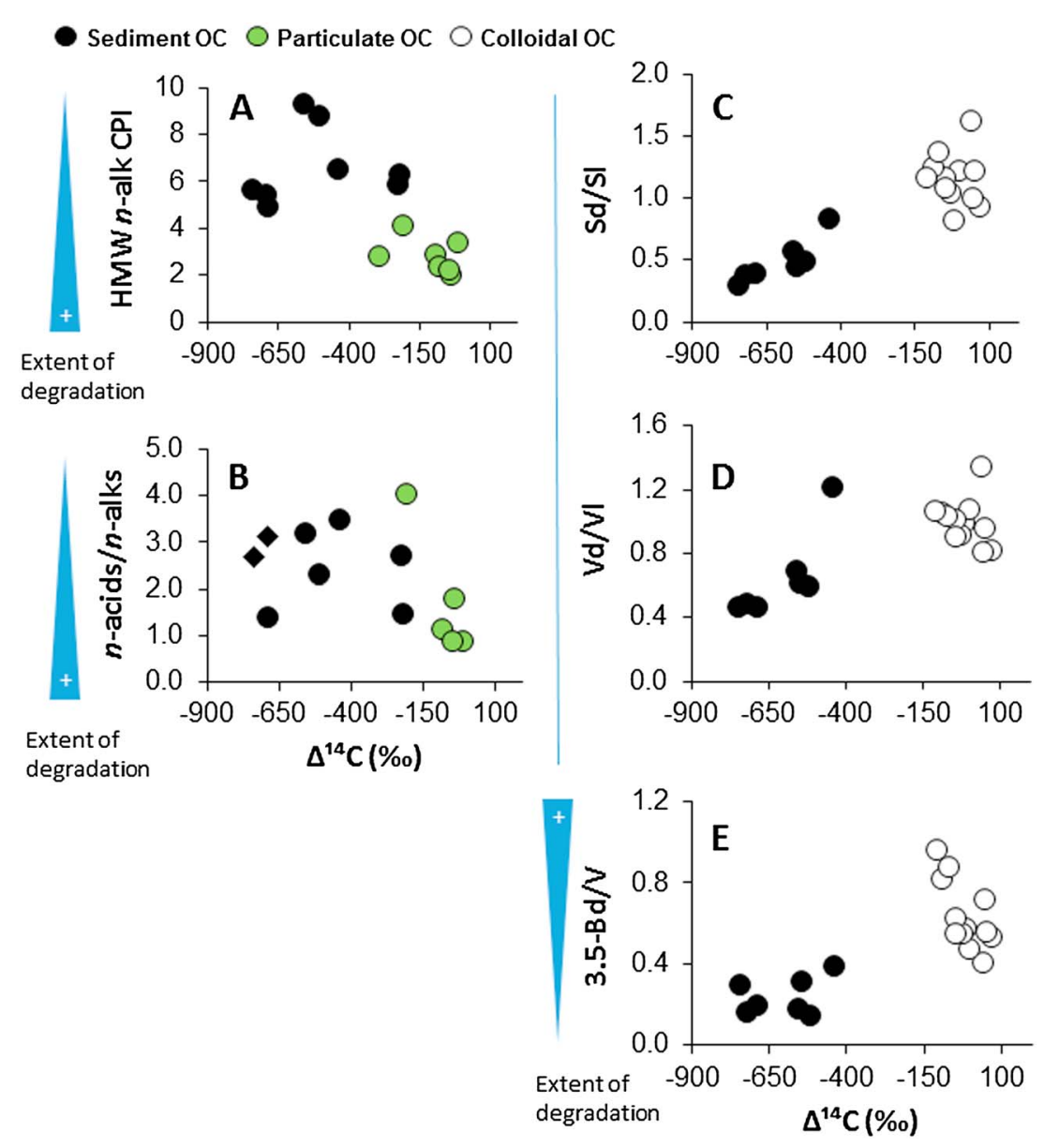

Figure 6. Comparison of molecular indices of organic matter degradation with age over the Eurasian Arctic margin. Degradation state proxies plotted over radiocarbon signal $\Delta^{14} \mathrm{C}(\%)$ in surface water colloidal OC (open circles), particulate OC (green circles), and in surface sediments (black circles) from July to August 2008 for the following proxies: (a) Carbon preference index (CPI) of

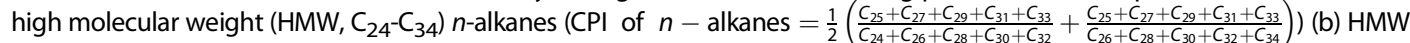
$n$-alkanoic acids $\left(\sum C_{20}-C_{32}\right)$ over HMW $n$-alkanes $\left(\sum C_{20}-C_{34}\right)$. (c-e) CuO oxidation reaction product-based proxies. Syringic acid over syringaldehyde (Figure 6c), vanillic acid over vanillin (Figure 6d), and 3,5-dihydroxybenzoic acid/vanillyl phenols (Figure 6e). Extent of degradation shown by proxy on blue scale bar, more degraded on thicker end for Figures $6 \mathrm{a}, 6 \mathrm{~b}$, and $6 \mathrm{e}$.

et al., 2005; Vonk et al., 2012]. Mineral association is commonly linked not only to settling of OC [Keil et al., 1994; Huguet et al., 2008] but also to degradation control and burial [Hedges et al., 1997, 2001]. A neutrally buoyant fraction that stays suspended in the surface water also has a longer exposure time in the oxygenated and photic part of the ocean. The suspended nature of COC implies a near absence of a heavy mineral component; its absence suggests that there is less protection against degradation due to mineral sorption. Both of these features promote degradation of the $\mathrm{COC}$ pool, which is corroborated by the biomarker assessment.

\section{Conclusions}

This study has demonstrated that the $\mathrm{COC}$ pool in coastal Eurasian Arctic waters has a distinctly different source than the POC and SOC pools. The COC is dominated by terrestrial OC from topsoil $(65 \% ; 31-90 \%)$ and marine plankton (25\%, 3-58\%) with only a very small component stemming from ICD-OC (9\%, 1-23\%). The COC thus contrasts starkly to POC and especially SOC, which both are dominated by ICD-OC. The partitioning difference between the carbon pools may reflect a compositional matrix difference, e.g., organomineral associations. The mineral-associated ICD-OC pool appears destined to rapid settling, as it is largely partitioned to the SOC pool. The ICD-OC can then experience cross-shelf transport during which the loss of carbon likely occurs over a centennial timescale. Settling of POC compared to COC may also reflect carbon loss differences, as mineral protection can be an important control on degradation. The terrestrial OC released in the DOC and COC is likely 
more exposed to degradation processes in the water column than SOC and POC. The patterns of COC distribution in this data set reflect different phenomena acting together, such as degradation of $\mathrm{COC}$, imprints from the dominant local river catchments, and dilution of riverine $\mathrm{COC}$ with $\mathrm{COC}$ already present in the ocean. This study resolves west-east differences, which could be attributed to differing river influences separate from dilution effects. More directed studies emphasizing higher temporal and spatial resolution will be needed to resolve and associate seasonality and episodic events. Different components of remobilized terrestrial permafrost OC may experience vastly different fate processes in response to climate change such as increase of river discharge and coastal erosion.

\section{Acknowledgments}

We thank the crew and personnel of the International Siberian Shelf Study 2008 (ISSS-08) and the crew of the subexpedition on board TB0012. The ISSS and SWERUS-C3 programs are supported by the Knut and Alice Wallenberg Foundation (contract 2011.0027), the Nordic Council of Ministries Cryosphere Climate Carbon Initiative (project DEFROST, contract 23001), the Government of the Russian Federation (grant 14, Z50.31.0012/ 03.19.2014), the Swedish Research Council (VR contracts 621-2004-4039, 621-2007-4631, and 621-2013-5297), the U.S. National Oceanic and Atmospheric Administration (Siberian Shelf Study), Headquarters of the Far Eastern Branch of the Russian Academy of Sciences, the Swedish Polar Research Secretariat, and the U.S. National Science Foundation (OPP ARC 1023281) T. Tesi acknowledges EU financial support as Marie Curie fellow (contract PIEF-GA-2011-300259), A. Charkin and O. Dudarev acknowledge support from the Russian Science Foundation (grant 15-17-20032), and B. van Dongen receipt of a NERC research grant (NE/I024798/1). We appreciate thoughtful comments by Anna Sobek and Brett Thornton on an earlier version of this manuscript. Data are available through the Bolin Centre Data Repository at Stockholm University, bolin.su.se/data.

\section{References}

Aagaard, K., and E. C. Carmack (1989), The role of sea ice and other fresh-water in the Arctic circulation, J. Geophys. Res., 94(C10), 14,485-14,498, doi:10.1029/JC094iC10p14485.

Aiken, G. R., R. G. M. Spencer, R. G. Striegl, P. F. Schuster, and P. A. Raymond (2014), Influences of glacier melt and permafrost thaw on the age of dissolved organic carbon in the Yukon River basin, Global Biogeochem. Cycles, 28, 525-537, doi:10.1002/2013GB004764.

Alling, V., et al. (2010), Nonconservative behavior of dissolved organic carbon across the Laptev and East Siberian seas, Global Biogeochem. Cycles, 24, GB4033, doi:10.1029/2010GB003834.

Alling, V., D. Porcelli, C. M. Morth, L. G. Anderson, L. Sanchez-Garcia, O. Gustafsson, P. S. Andersson, and C. Humborg (2012), Degradation of terrestrial organic carbon, primary production and out-gassing of $\mathrm{CO}_{2}$ in the Laptev and East Siberian Seas as inferred from delta C-13 values of DIC, Geochim. Cosmochim. Acta, 95, 143-159.

Amon, R. M. W., et al. (2012), Dissolved organic matter sources in large Arctic Rivers, Geochim. Cosmochim. Acta, 94, $217-237$.

Anderson, L. G., S. Jutterstrom, S. Hjalmarsson, I. Wahlstrom, and I. P. Semiletov (2009), Out-gassing of CO2 from Siberian shelf seas by terrestrial organic matter decomposition, Geophys. Res. Lett., 36, L20601, doi:10.1029/2009GL040046.

Andersson, A. (2011), A systematic examination of a random sampling strategy for source apportionment calculations, Sci. Total Environ., 412, 232-238.

Andersson, P. S., D. Porcelli, J. Gelting, F. Nordblad, O. Gustafsson, and I. Semiletov (2009), The importance of river water inflow and shelf sedimentsea water exchange in the East Siberian Sea for the Nd isotopic composition of Arctic Ocean water, Geochim. Cosmochim. Acta, 73(13), A41-A41.

Are, F., M. N. Grigoriev, H.-W. Hubberten, V. Rachold, S. Razumov, and W. Schneider (2002), Comparative shoreface evolution along the Laptev Sea coast, Polarforschung, 70, 135-150.

Are, F. E. (1999), The role of coastal retreat for sedimentation in the Laptev Sea, in Land-Ocean Systems in the Siberian Arctic, edited by H. Kassens et al., pp. 288-295, Springer, Berlin Heidelberg.

Asplin, M. G., R. Galley, D. G. Barber, and S. Prinsenberg (2012), Fracture of summer perennial sea ice by ocean swell as a result of Arctic storms, J. Geophys. Res., 117, C06025, doi:10.1029/2011JC007221.

Bauch, D., I. Dmitrenko, S. Kirillov, C. Wegner, J. Holemann, S. Pivovarov, L. Timokhov, and H. Kassens (2009), Eurasian Arctic shelf hydrography: Exchange and residence time of southern Laptev Sea waters, Cont. Shelf Res., 29(15), 1815-1820.

Benner, R., B. Benitez-Nelson, K. Kaiser, and R. M. W. Amon (2004), Export of young terrigenous dissolved organic carbon from rivers to the Arctic Ocean, Geophys. Res. Lett., 31, L05305, doi:10.1029/2003GL019251.

Bianchi, T. S., and M. A. Allison (2009), Large-river delta-front estuaries as natural "recorders" of global environmental change, Proc. Natl. Acad. Sci. U.S.A., 106(20), 8085-8092.

Brassell, S., and G. Eglinton (1983), Steroids and triterpenoids in deep sea sediments as environmental and diagenetic indicators, Adv. Org. Geochem., 1981, 684-697.

Brassell, S. C., J. McEvoy, C. F. Hoffmann, N. A. Lamb, T. M. Peakman, and J. R. Maxwell (1984), Isomerisation, rearrangement and aromatisation of steroids in distinguishing early stages of diagenesis, Org. Geochem., 6, 11-23, doi:10.1016/0146-6380(84)90022-6.

Breckle, S. W., and H. Walter (2002), Walter's Vegetation of the Earth, pp. 527, Springer, Berlin.

Brown, J., O. Ferrians, J. A. Heginbottom, and E. Melnikov (2014), Circum-Arctic Map of Permafrost and Ground-Ice Conditions, National Snow and Ice Data Center, Boulder, Colo.

Cauwet, G., and I. Sidorov (1996), The biogeochemistry of Lena River: Organic carbon and nutrients distribution, Mar. Chem., 53(3), $211-227$.

Charkin, A. N., O. V. Dudarev, I. P. Semiletov, A. V. Kruhmalev, J. E. Vonk, L. Sanchez-Garcia, E. Karlsson, and O. Gustafsson (2011), Seasonal and interannual variability of sedimentation and organic matter distribution in the Buor-Khaya Gulf: The primary recipient of input from Lena River and coastal erosion in the southeast Laptev Sea, Biogeosciences, 8(9), 2581-2594.

Cooper, L. W., R. Benner, J. W. McClelland, B. J. Peterson, R. M. Holmes, P. A. Raymond, D. A. Hansell, J. M. Grebmeier, and L. A. Codispoti (2005), Linkages among runoff, dissolved organic carbon, and the stable oxygen isotope composition of seawater and other water mass indicators in the Arctic Ocean, J. Geophys. Res., 110, G02013, doi:10.1029/2005JG000031.

Coppola, L., O. Gustafsson, P. Andersson, T. I. Eglinton, M. Uchida, and A. F. Dickens (2007), The importance of ultrafine particles as a control on the distribution of organic carbon in Washington Margin and Cascadia Basin sediments, Chem. Geol., 243(1-2), 142-156.

Degens, E. T. (1969), Biogeochemsitry of stable carbon isotopes, in Organic Geochemistry: Methods and Results. Xxiv + 828p. Illus. Maps, edited by G. Eglinton and M. T. J. Murphy, pp. 304-329, Springer-Verlag, New York; Berlin, W. Germany.

Dickens, A. F., J. A. Gudeman, Y. Gelinas, J. A. Baldock, W. Tinner, F. S. Hu, and J. I. Hedges (2007), Sources and distribution of CuO-derived benzene carboxylic acids in soils and sediments, Org. Geochem., 38(8), 1256-1276.

Doğrul Selver, A., R. B. Sparkes, J. Bischoff, H. M. Talbot, Ö. M. Gustafsson, I. P. Semiletov, O. V. Dudarev, S. Boult, and B. E. van Dongen (2015), Distributions of bacterial and archaeal membrane lipids in surface sediments reflect differences in input and loss of terrestrial organic carbon along a cross-shelf Arctic transect, Org. Geochem., 83-84, 16-26.

Dudarev, O. V., I. P. Semiletov, A. N. Charkin, and A. I. Botsul (2006), Deposition settings on the continental shelf of the East Siberian Sea, Dokl. Earth Sci., 409(6), 1000-1005.

Eglinton, G., and R. J. Hamilton (1967), Leaf epicuticular waxes, Science, 156(3780), 1322-1335.

Fahl, K., and R. Stein (1997), Modern organic carbon deposition in the Laptev Sea and the adjacent continental slope: Surface water productivity vs. terrigenous input, Org. Geochem., 26(5-6), 379-390.

Farrington, J. W., and B. W. Tripp (1977), Hydrocarbons in western north-Atlantic surface sediments, Geochim. Cosmochim. Acta, 41(11), 1627-1641. 
Feng, X., J. E. Vonk, B. E. van Dongen, O. Gustafsson, I. P. Semiletov, O. V. Dudarev, Z. Wang, D. B. Montlucon, L. Wacker, and T. I. Eglinton (2013), Differential mobilization of terrestrial carbon pools in Eurasian Arctic River basins, Proc. Natl. Acad. Sci. U.S.A., 110(35), 14,168-14,173.

Feng, X., et al. (2015), Multi-molecular tracers of terrestrial carbon transfer across the pan-Arctic: Comparison of hydrolyzable components with plant wax lipids and lignin phenols, Biogeosciences, 12(15), 4841-4860.

Fontugne, M., and J. C. Duplessy (1978), Carbon isotope ratio of marine plankton related to surface-water masses, Earth Planet. Sci. Lett., 41(3), 365-371.

Frey, K. E., and J. W. McClelland (2009), Impacts of permafrost degradation on Arctic River biogeochemistry, Hydrol. Processes, 23(1), 169-182. Galimov, E. M., L. A. Kodina, O. V. Stepanets, and G. S. Korobeinik (2006), Biogeochemistry of the Russian Arctic. Kara Sea: Research results under the SIRRO project, 1995-2003, Geochem. Int., 44(11), 1053-1104.

Goering, J., V. Alexander, and N. Haubenstock (1990), Seasonal variability of stable carbon and nitrogen isotope ratios of organisms in a North Pacific Bay, Estuarine Coastal Shelf Sci., 30(3), 239-260, doi:10.1016/0272-7714(90)90050-2.

Goni, M. A., and J. I. Hedges (1990), Cutin-derived CuO reaction-products from purified cuticle and tree leaves, Geochim. Cosmochim. Acta, 54(11), 3065-3072.

Goni, M. A., and J. I. Hedges (1995), Sources and reactivities of marine-derived organic-matter in coastal sediments as determined by alkaline CuO oxidation, Geochim. Cosmochim. Acta, 59(14), 2965-2981.

Goni, M. A., and S. Montgomery (2000), Alkaline CuO oxidation with a microwave digestion system: Lignin analyses of geochemical samples, Anal. Chem., 72(14), 3116-3121.

Goni, M. A., M. B. Yunker, R. W. Macdonald, and T. I. Eglinton (2000), Distribution and sources of organic biomarkers in Arctic sediments from the Mackenzie River and Beaufort Shelf, Mar. Chem., 71(1-2), 23-51.

Goni, M. A., M. B. Yunker, R. W. Macdonald, and T. I. Eglinton (2005), The supply and preservation of ancient and modern components of organic carbon in the Canadian Beaufort Shelf of the Arctic Ocean, Mar. Chem., 93(1), 53-73.

Goni, M. A., A. E. O'Connor, Z. Z. Kuzyk, M. B. Yunker, C. Gobeil, and R. W. Macdonald (2013), Distribution and sources of organic matter in surface marine sediments across the North American Arctic margin, J. Geophys. Res. Oceans, 118, 4017-4035, doi:10.1002/jgrc.20286.

Gordeev, V. V., J. M. Martin, I. S. Sidorov, and M. V. Sidorova (1996), A reassessment of the Eurasian river input of water, sediment, major elements, and nutrients to the Arctic Ocean, Am. J. Sci., 296(6), 664-691.

Grigoriev, M. N., S. O. Razumov, V. V. Kunitzkiy, and V. B. Spektor (2006), Dynamics of the Russian east Arctic Sea coast: Major factors, regularities and tendencies, Earth's Cryosphere, 10(4), 74-94

Gu, B., D. M. Schell, and V. Alexander (1994), Stable carbon and nitrogen isotopic analysis of the plankton food web in a subarctic lake, Can. J. Fish. Aquat. Sci., 51(6), 1338-1344.

Günther, F., P. P. Overduin, A. V. Sandakov, G. Grosse, and M. N. Grigoriev (2013), Short- and long-term thermo-erosion of ice-rich permafrost coasts in the Laptev Sea region, Biogeosciences, 10(6), 4297-4318.

Guo, L. D., and R. W. Macdonald (2006), Source and transport of terrigenous organic matter in the upper Yukon River: Evidence from isotope (delta C-13, Delta C-14, and delta N-15) composition of dissolved, colloidal, and particulate phases, Global Biogeochem. Cycles, 20, GB2011, doi:10.1029/2005GB002593.

Guo, L. D., I. Semiletov, O. Gustafsson, J. Ingri, P. Andersson, O. Dudarev, and D. White (2004), Characterization of Siberian Arctic coastal sediments: Implications for terrestrial organic carbon export, Global Biogeochem. Cycles, 18, GB1036, doi:10.1029/2003GB002087.

Guo, L. D., C. L. Ping, and R. W. Macdonald (2007), Mobilization pathways of organic carbon from permafrost to Arctic Rivers in a changing climate, Geophys. Res. Lett., 34, L13603, doi:10.1029/2007GL030689.

Gustafsson, O., and P. M. Gschwend (1997), Aquatic colloids: Concepts, definitions, and current challenges, Limnol. Oceanogr., 42(3), 519-528.

Gustafsson, O., B. E. van Dongen, J. E. Vonk, O. V. Dudarev, and I. P. Semiletov (2011), Widespread release of old carbon across the Siberian Arctic echoed by its large rivers, Biogeosciences, 8(6), 1737-1743.

Hedges, J. I., and D. C. Mann (1979), Characterization of plant-tissues by their lignin oxidation-products, Geochim. Cosmochim. Acta, 43(11), 1803-1807.

Hedges, J. I., W. A. Clark, P. D. Quay, J. E. Richey, A. H. Devol, and U. D. Santos (1986), Compositions and fluxes of particulate organic material in the Amazon River, Limnol. Oceanogr., 31(4), 717-738.

Hedges, J. I., W. A. Clark, and G. L. Cowie (1988), Organic matter sources to the water column and surficial sediments of a marine bay, Limnol. Oceanogr., 33(5), 1116-1136.

Hedges, J. I., R. G. Keil, and R. Benner (1997), What happens to terrestrial organic matter in the ocean?, Org. Geochem., 27(5-6), 195-212.

Hedges, J. I., J. A. Baldock, Y. Gelinas, C. Lee, M. Peterson, and S. G. Wakeham (2001), Evidence for non-selective preservation of organic matter in sinking marine particles, Nature, 409(6822), 801-804.

Hernes, P. J., and R. Benner (2003), Photochemical and microbial degradation of dissolved lignin phenols: Implications for the fate of terrigenous dissolved organic matter in marine environments, J. Geophys. Res., 108(C9), 3291, doi:10.1029/2002JC001421.

Holmes, R. M., J. W. McClelland, B. J. Peterson, I. A. Shiklomanov, A. I. Shiklomanov, A. V. Zhulidov, V. V. Gordeev, and N. N. Bobrovitskaya (2002), A circumpolar perspective on fluvial sediment flux to the Arctic Ocean, Global Biogeochem. Cycles, 16(4), 1098, doi:10.1029/2001GB001849.

Holmes, R. M., et al. (2012), Seasonal and annual fluxes of nutrients and organic matter from large rivers to the Arctic Ocean and surrounding seas, Estuaries Coasts, 35(2), 369-382.

Houel, S., P. Louchouarn, M. Lucotte, R. Canuel, and B. Ghaleb (2006), Translocation of soil organic matter following reservoir impoundment in boreal systems: Implications for in situ productivity, Limnol. Oceanogr., 51(3), 1497-1513.

Huguet, C., G. J. de Lange, O. Gustafsson, J. J. Middelburg, J. S. S. Damste, and S. Schouten (2008), Selective preservation of soil organic matter in oxidized marine sediments (Madeira Abyssal Plain), Geochim. Cosmochim. Acta, 72(24), 6061-6068.

Kaplina, T. N. (1959), Nekotorye Osobennosti Razmyva Beregov, Slozhennykh Mnogoletnemerzlymi Gornymi Porodami (Some Features of Coastal Thermoerosion of Frozen Bluffs), pp. 113-117, USSR Academy of Sciences, Moscow.

Karlsson, E. S., A. Charkin, O. Dudarev, I. Semiletov, J. E. Vonk, L. Sanchez-Garcia, A. Andersson, and O. Gustafsson (2011), Carbon isotopes and lipid biomarker investigation of sources, transport and degradation of terrestrial organic matter in the Buor-Khaya Bay, SE Laptev Sea, Biogeosciences, 8(7), 1865-1879, doi:10.5194/bg-8-1865-2011.

Keil, R. G., D. B. Montlucon, F. G. Prahl, and J. I. Hedges (1994), Sorptive preservation of labile organic-matter in marine sediment, Nature, 370(6490), 549-552.

Kling, G. W., B. Fry, and W. J. O'Brien (1992), Stable isotopes and planktonic trophic structure in arctic lakes, Ecology, 73(2), 561-566.

Kolattukudy, P. E., and T. J. Walton (1972), Structure and biosynthesis of hydroxy fatty-acids of cutin and Vicia-Faba leaves, Biochemistry, 11(10), 1897-1907.

Kraberg, A. C., E. Druzhkova, B. Heim, M. J. G. Loeder, and K. H. Wiltshire (2013), Phytoplankton community structure in the Lena Delta (Siberia, Russia) in relation to hydrography, Biogeosciences, 10(11), 7263-7277, doi:10.5194/bg-10-7263-2013. 
Lantuit, H., et al. (2012), The Arctic coastal dynamics database: A new classification scheme and statistics on Arctic permafrost coastlines, Estuaries Coasts, 35(2), 383-400.

Lantuit, H., P. P. Overduin, and S. Wetterich (2013), Recent progress regarding permafrost coasts, Permafrost Periglac. Process., 24(2), 120-130.

Lara, R. J., V. Rachold, G. Kattner, H. W. Hubberten, G. Guggenberger, A. Skoog, and D. N. Thomas (1998), Dissolved organic matter and nutrients in the Lena River, Siberian Arctic: Characteristics and distribution, Mar. Chem., 59(3-4), 301-309.

Larsson, J., O. Gustafsson, and J. Ingri (2002), Evaluation and optimization of two complementary cross-flow ultrafiltration systems toward isolation of coastal surface water colloids, Environ. Sci. Technol., 36(10), 2236-2241.

Lobbes, J. M., H. P. Fitznar, and G. Kattner (2000), Biogeochemical characteristics of dissolved and particulate organic matter in Russian Rivers entering the Arctic Ocean, Geochim. Cosmochim. Acta, 64(17), 2973-2983.

Louchouarn, P., S. Opsahl, and R. Benner (2000), Isolation and quantification of dissolved lignin from natural waters using solid-phase extraction and GC/MS, Anal. Chem., 72(13), 2780-2787.

Lyon, S. W., and G. Destouni (2010), Changes in catchment-scale recession flow properties in response to permafrost thawing in the Yukon River basin, Int. J. Climatol., 30(14), 2138-2145.

MacDonald, G. M., D. W. Beilman, K. V. Kremenetski, Y. Sheng, L. C. Smith, and A. A. Velichko (2006), Rapid early development of circumarctic peatlands and atmospheric $\mathrm{CH}_{4}$ and $\mathrm{CO}_{2}$ variations, Science, 314(5797), 285-288.

Manizza, M., M. J. Follows, S. Dutkiewicz, J. W. McClelland, D. Menemenlis, C. N. Hill, A. Townsend-Small, and B. J. Peterson (2009), Modeling transport and fate of riverine dissolved organic carbon in the Arctic Ocean, Global Biogeochem. Cycles, 23, GB4006, doi:10.1029/2008GB003396.

Mann, P. J., A. Davydova, N. Zimov, R. G. M. Spencer, S. Davydov, E. Bulygina, S. Zimov, and R. M. Holmes (2012), Controls on the composition and lability of dissolved organic matter in Siberia's Kolyma River basin, J. Geophys. Res., 117, G01028, doi:10.1029/2011JG001798.

McClelland, J. W., et al. (2008), Development of a Pan-Arctic database for river chemistry, Eos Trans. AGU, 89(24), 217-218, doi:10.1029/ 2008EO240001.

McClelland, J. W., R. M. Holmes, K. H. Dunton, and R. W. Macdonald (2012), The Arctic Ocean estuary, Estuaries Coasts, 35(2), 353-368.

McGuire, A. D., F. S. Chapin, J. E. Walsh, and C. Wirth (2006), Integrated regional changes in Arctic climate feedbacks: Implications for the global climate system, Annu. Rev. Environ. Resour., 31, 61-91.

Neff, J. C., J. C. Finlay, S. A. Zimov, S. P. Davydov, J. J. Carrasco, E. A. G. Schuur, and A. I. Davydova (2006), Seasonal changes in the age and structure of dissolved organic carbon in Siberian rivers and streams, Geophys. Res. Lett., 33, L23401, doi:10.1029/2006GL028222.

Nicolsky, D., and N. Shakhova (2010), Modeling sub-sea permafrost in the East Siberian Arctic shelf: The Dmitry Laptev strait, Environ. Res. Lett., 5(1).

Opsahl, S., and R. Benner (1995), Early diagenesis of vascular plant tissues: Lignin and cutin decomposition and biogeochemical implications, Geochim. Cosmochim. Acta, 59(23), 4889-4904.

Opsahl, S., and R. Benner (1998), Photochemical reactivity of dissolved lignin in river and ocean waters, Limnol. Oceanogr., 43(6), 1297-1304.

Opsahl, S., R. Benner, and R. M. W. Amon (1999), Major flux of terrigenous dissolved organic matter through the Arctic Ocean, Limnol. Oceanogr., 44(8), 2017-2023.

Otto, A., and M. J. Simpson (2006), Evaluation of CuO oxidation parameters for determining the source and stage of lignin degradation in soil, Biogeochemistry, 80(2), 121-142, doi:10.1007/s10533-006-9014-x.

Overeem, I., R. S. Anderson, C. W. Wobus, G. D. Clow, F. E. Urban, and N. Matell (2011), Sea ice loss enhances wave action at the Arctic coast, Geophys. Res. Lett., 38, L17503, doi:10.1029/2011GL048681.

Pasqual, C., C. Lee, M. Goñi, T. Tesi, A. Sanchez-Vidal, A. Calafat, M. Canals, and S. Heussner (2011), Use of organic biomarkers to trace the transport of marine and terrigenous organic matter through the southwestern canyons of the Gulf of Lion, Mar. Chem., 126(1), 1-12.

Peterson, B. J., R. M. Holmes, J. W. McClelland, C. J. Vorosmarty, R. B. Lammers, A. I. Shiklomanov, I. A. Shiklomanov, and S. Rahmstorf (2002), Increasing river discharge to the Arctic Ocean, Science, 298(5601), 2171-2173.

Pipko, I. I., I. A. Repina, A. N. Salyuk, I. P. Semiletov, and S. P. Pugach (2008), Comparison of calculated and measured $\mathrm{CO}_{2}$ fluxes between the ocean and atmosphere in the southwestern part of the East Siberia Sea, Dokl. Earth Sci., 422(1), 1105-1108.

Pokrovsky, O. S., J. Viers, L. S. Shirokova, V. P. Shevchenko, A. S. Filipov, and B. Dupre (2010), Dissolved, suspended, and colloidal fluxes of organic carbon, major and trace elements in the Severnaya Dvina River and its tributary, Chem. Geol., 273(1-2), 136-149.

Pokrovsky, O. S., et al. (2014), Fate of colloids during estuarine mixing in the Arctic, Ocean Sci., 10(1), 107-125.

Prahl, F. G., J. R. Ertel, M. A. Goni, M. A. Sparrow, and B. Eversmeyer (1994), Terrestrial organic-carbon contributions to sediments on the Washington margin, Geochim. Cosmochim. Acta, 58(14), 3035-3048.

Rachold, V., and H.-W. Hubberten (1999), Carbon and nitrogen analysis on water samples from Siberian Rivers, Pangaea, doi:10.1594/ PANGAEA.55746.

Rachold, V., A. Alabyan, H. W. Hubberten, V. N. Korotaev, and A. A. Zaitsev (1996), Sediment transport to the Laptev Sea-Hydrology and geochemistry of the Lena River, Polar Res., 15(2), 183-196.

Rachold, V., M. N. Grigoriev, F. E. Are, S. Solomon, E. Reimnitz, H. Kassens, and M. Antonow (2000), Coastal erosion vs riverine sediment discharge in the Arctic Shelf seas, Int. J. Earth Sci., 89(3), 450-460.

Raymond, P. A., J. W. McClelland, R. M. Holmes, A. V. Zhulidov, K. Mull, B. J. Peterson, R. G. Striegl, G. R. Aiken, and T. Y. Gurtovaya (2007), Flux and age of dissolved organic carbon exported to the Arctic Ocean: A carbon isotopic study of the five largest Arctic Rivers, Global Biogeochem. Cycles, 21, GB4011, doi:10.1029/2007GB002934.

Rieley, G., R. J. Collier, D. M. Jones, and G. Eglinton (1991), The biogeochemistry of Ellesmere lake, UK. 1. Source correlation of leaf wax inputs to the sedimentary lipid record, Org. Geochem., 17(6), 901-912.

Romanovsky, V. E., T. S. Sazonova, V. T. Balobaev, N. I. Shender, and D. O. Sergueev (2007), Past and recent changes in air and permafrost temperatures in eastern Siberia, Global Planet. Change, 56(3-4), 399-413.

Sanchéz-García, L., V. Alling, S. Pugach, J. Vonk, B. van Dongen, C. Humborg, O. Dudarev, I. Semiletov, and O. Gustafsson (2011), Inventories and behavior of particulate organic carbon in the Laptev and East Siberian seas, Global Biogeochem. Cycles, 25, GB2007, doi:10.1029/2010GB003862.

Sanchez-Garcia, L., J. E. Vonk, A. N. Charkin, D. Kosmach, O. V. Dudarev, I. P. Semiletov, and O. Gustafsson (2014), Characterisation of three regimes of collapsing Arctic Ice Complex Deposits on the SE Laptev Sea coast using biomarkers and dual carbon isotopes, Permafrost Periglac. Process., 25(3), 172-183.

Sarkanen, K. V., and C. H. Ludwig (1971), Lignins: Occurrence, Formation, Structure and Reactions, Wiley-Interscience, New York.

Schirrmeister, L., D. Froese, V. Tumskoy, G. Grosse, and S. Wetterich (2013), Yedoma: Late Pleistocene ice-rich syngenetic permafrost of Beringia, in Encyclopedia of Quaternary Science, edited by S. A. Elias, C. J. Mock, and J. Murton, pp. 542-552, Elsevier, Amsterdam.

Schreiner, K. M., T. S. Bianchi, and B. E. Rosenheim (2014), Evidence for permafrost thaw and transport from an Alaskan north slope watershed, Geophys. Res. Lett., 41, 3117-3126, doi:10.1002/2014GL059514.

Schubert, C. J., and R. Stein (1996), Deposition of organic carbon in Arctic Ocean sediments: Terrigenous supply vs marine productivity, Org. Geochem., 24(4), 421-436. 
Semiletov, I., O. Dudarev, V. Luchin, A. Charkin, K. H. Shin, and N. Tanaka (2005), The East Siberian Sea as a transition zone between Pacific-derived waters and Arctic shelf waters, Geophys. Res. Lett., 32, L10614, doi:10.1029/2005GL022490.

Semiletov, I. P. (1999), Destruction of the coastal permafrost ground as an important factor in biogeochemistry of the Arctic Shelf waters (translated into English), Trans. (Dokl.) Russ. Acad. Sci., 368, 679-682.

Semiletov, I. P., and Ö. Gustafsson (2009), East Siberian shelf study alleviates scarcity of observations, Eos Trans. AGU, 90(17), 145-146, doi:10.1029/2009EO170001.

Semiletov, I. P., N. E. Shakhova, V. I. Sergienko, I. I. Pipko, and O. V. Dudarev (2012), On carbon transport and fate in the East Siberian Arctic land-shelf-atmosphere system, Environ. Res. Lett., 7(1), 015201.

Semiletov, I. P., N. E. Shakhova, I. I. Pipko, S. P. Pugach, A. N. Charkin, O. V. Dudarev, D. A. Kosmach, and S. Nishino (2013), Space-time dynamics of carbon and environmental parameters related to carbon dioxide emissions in the Buor-Khaya Bay and adjacent part of the Laptev Sea, Biogeosciences, 10(9), 5977-5996.

Serreze, M. C., D. H. Bromwich, M. P. Clark, A. J. Etringer, T. J. Zhang, and R. Lammers (2003), Large-scale hydro-climatology of the terrestrial Arctic drainage system, J. Geophys. Res., 108(D2), 8160, doi:10.1029/2001JD000919.

Shakhova, N., et al. (2014), Ebullition and storm-induced methane release from the East Siberian Arctic shelf, Nat. Geosci., 7(1), 64-70.

Shakhova, N. E., D. Y. Nicolsky, and I. P. Semiletov (2009a), Current state of subsea permafrost on the East Siberian shelf: Tests of modeling results based on field observations, Dokl. Earth Sci., 429(2), 1518-1521.

Shakhova, N. E., V. I. Sergienko, and I. P. Semiletov (2009b), The contribution of the East Siberian shelf to the modern methane cycle, Her. Russ. Acad. Sci., 79(3), 237-246.

Sharp, J. H., R. Benner, L. Bennett, C. A. Carlson, S. E. Fitzwater, E. T. Peltzer, and L. M. Tupas (1995), Analyses of dissolved organic-carbon in seawater: The JGOFS EQPAC methods comparison, Mar. Chem., 48(2), 91-108.

Simoneit, B. R. T. (1977), Black Sea, a sink for terrigenous lipids, Deep Sea Res., 24(9), 813-830.

Spencer, R. G. M., G. R. Aiken, K. P. Wickland, R. G. Striegl, and P. J. Hernes (2008), Seasonal and spatial variability in dissolved organic matter quantity and composition from the Yukon River basin, Alaska, Global Biogeochem. Cycles, 22, GB4002, doi:10.1029/2008GB003231.

Steele, M., and W. Ermold (2004), Salinity trends on the Siberian shelves, Geophys. Res. Lett., 31, L24308, doi:10.1029/2004GL021302.

Stein, R., and R. W. Macdonald (2004), The Organic Carbon Cycle in the Arctic Ocean, Springer, Berlin, Germany.

Stein, R., K. Fahl, D. K. Fiitterer, E. M. Galimov, and O. V. Stepanets (2003), Siberian River Run-Off Into the Kara Sea: Characterization, Quantification, Variability and Environmental Significance-An Introduction, vol. 6, pp. 496, Elsevier Science.

Striegl, R. G., G. R. Aiken, M. M. Dornblaser, P. A. Raymond, and K. P. Wickland (2005), A decrease in discharge-normalized DOC export by the Yukon River during summer through autumn, Geophys. Res. Lett., 32, L21413, doi:10.1029/2005GL024413.

Striegl, R. G., M. M. Dornblaser, G. R. Aiken, K. P. Wickland, and P. A. Raymond (2007), Carbon export and cycling by the Yukon, Tanana, and Porcupine rivers, Alaska, 2001-2005, Water Resour. Res., 43, W02411, doi:10.1029/2006WR005201.

Tesi, T., L. Langone, M. A. Goñi, S. Miserocchi, and F. Bertasi (2008), Changes in the composition of organic matter from prodeltaic sediments after a large flood event (Po River, Italy), Geochim. Cosmochim. Acta, 72(8), 2100-2114, doi:10.1016/j.gca.2008.02.005.

Tesi, T., I. Semiletov, G. Hugelius, O. Dudarev, P. Kuhry, and Ö. Gustafsson (2014), Composition and fate of terrigenous organic matter along the Arctic land-ocean continuum in East Siberia: Insights from biomarkers and carbon isotopes, Geochim. Cosmochim. Acta, 133, 235-256.

Tulloch, A. P. (1976), Chemistry of waxes of higher plants, in Chemistry and Biochemistry of Natural Waxes, edited by P. E. Kolattukudy, pp. 235-287, Elsevier, New York.

van Dongen, B. E., I. Semiletov, J. W. H. Weijers, and O. R. Gustafsson (2008a), Contrasting lipid biomarker composition of terrestrial organic matter exported from across the Eurasian Arctic by the five great Russian Arctic Rivers, Global Biogeochem. Cycles, 22, GB1011, doi:10.1029/2007GB002974.

van Dongen, B. E., Z. Zencak, and O. Gustafsson (2008b), Differential transport and degradation of bulk organic carbon and specific terrestria biomarkers in the surface waters of a sub-arctic brackish bay mixing zone, Mar. Chem., 112(3-4), 203-214.

Vonk, J. E., and O. Gustafsson (2013), Permafrost-carbon complexities, Nat. Geosci., 6(9), 675-676.

Vonk, J. E., B. E. van Dongen, and O. Gustafsson (2010a), Selective preservation of old organic carbon fluvially released from sub-Arctic soils, Geophys. Res. Lett., 37, L11605, doi:10.1029/2010GL042909.

Vonk, J. E., L. Sanchez-Garcia, I. Semiletov, O. Dudarev, T. Eglinton, A. Andersson, and O. Gustafsson (2010b), Molecular and radiocarbon constraints on sources and degradation of terrestrial organic carbon along the Kolyma paleoriver transect, East Siberian Sea, Biogeosciences, 7(10), 3153-3166.

Vonk, J., L. Sánchez-García, B. Van Dongen, V. Alling, D. Kosmach, A. Charkin, I. Semiletov, O. Dudarev, N. Shakhova, and P. Roos (2012), Activation of old carbon by erosion of coastal and subsea permafrost in Arctic Siberia, Nature, 489(7414), 137-140.

Vonk, J. E., P. J. Mann, S. Davydov, A. Davydova, R. G. Spencer, J. Schade, W. V. Sobczak, N. Zimov, S. Zimov, and E. Bulygina (2013), High biolability of ancient permafrost carbon upon thaw, Geophys. Res. Lett., 40, 2689-2693, doi:10.1002/grl.50348.

Vonk, J. E., I. P. Semiletov, O. V. Dudarev, T. I. Eglinton, A. Andersson, N. Shakhova, A. Charkin, B. Heim, and O. Gustafsson (2014), Preferential burial of permafrost-derived organic carbon in Siberian-Arctic shelf waters, J. Geophys. Res. Oceans, 119, 8410-8421, doi:10.1002/2014JC010261.

Vonk, J. E., S. E. Tank, P. J. Mann, R. G. M. Spencer, C. C. Treat, R. G. Striegl, B. W. Abbott, and K. P. Wickland (2015), Biodegradability of dissolved organic carbon in permafrost soils and aquatic systems: A meta-analysis, Biogeosciences, 12(23), 6915-6930, doi:10.5194/ bg-12-6915-2015.

Wegner, C., J. A. Holemann, I. Dmitrenko, S. Kirillov, and H. Kassens (2005), Seasonal variations in Arctic sediment dynamics-Evidence from 1 -year records in the Laptev Sea (Siberian Arctic), Global Planet. Change, 48(1-3), 126-140.

Williams, C. J., J. B. Yavitt, R. K. Wieder, and N. L. Cleavitt (1998), Cupric oxide oxidation products of northern peat and peat-forming plants, Can. J. Bot., 76(1), 51-62.

Winterfeld, M., M. A. Goñi, J. Just, J. Hefter, and G. Mollenhauer (2015), Characterization of particulate organic matter in the Lena River delta and adjacent nearshore zone, NE Siberia — Part 2: Lignin-derived phenol compositions, Biogeosciences, 12, 2261-2283, doi:10.5194/bg-12-2261-2015.

Yunker, M. B., L. R. Snowdon, R. W. MacDonald, J. N. Smith, M. G. Fowler, D. N. Skibo, F. A. McLaughlin, A. I. Danyushevskaya, V. I. Petrova, and G. I. Ivanov (1996), Polycyclic aromatic hydrocarbon composition and potential sources for sediment samples from the Beaufort and Barents Seas, Environ. Sci. Technol., 30(4), 1310-1320.

Yunker, M. B., L. L. Belicka, H. R. Harvey, and R. W. Macdonald (2005), Tracing the inputs and fate of marine and terrigenous organic matter in Arctic Ocean sediments: A multivariate analysis of lipid biomarkers, Deep Sea Res. Part II, 52(24-26), 3478-3508.

Yunker, M. B., R. W. Macdonald, L. R. Snowdon, and B. R. Fowler (2011), Alkane and PAH biomarkers as tracers of terrigenous organic carbon in Arctic Ocean sediments, Org. Geochem., 42(9), 1109-1146. 